\title{
Responses of food web to hypolimnetic aeration in Lake Vesijärvi
}

\author{
Jukka Ruuhijärvi (iD · Tommi Malinen · Kirsi Kuoppamäki • Pasi Ala-Opas • \\ Mika Vinni
}

Received: 15 August 2019/Revised: 29 May 2020/ Accepted: 1 June 2020/Published online: 12 June 2020

(C) The Author(s) 2020

\begin{abstract}
We studied the responses of a food web, especially fish and zooplankton, to summertime aeration, pumping of oxygen-rich epilimnetic water to the hypolimnion in Lake Vesijärvi, southern Finland. The aim of hypolimnetic aeration was to reduce internal loading of phosphorus from sediment. The population of smelt (Osmerus eperlanus L.), the main planktivore of the pelagial area, collapsed during the two 1st years of aeration due to increased temperature and low oxygen concentrations in the hypolimnion. The population recovered after the 4th year of hypolimnetic aeration, when oxygen conditions were improved. Despite elevated hypolimnetic
\end{abstract}

Guest editors: Tom Jilbert, Raoul-Marie Couture,

Brian J. Huser \& Kalevi Salonen / Restoration of eutrophic lakes: current practices and future challenges

J. Ruuhijärvi $(\bowtie) \cdot$ P. Ala-Opas

Natural Resources Institute Finland, Latokartanonkaari 9, 00791 Helsinki, Finland

e-mail: jukka.ruuhijarvi@luke.fi

T. Malinen · M. Vinni

Ecosystems and Environment Research Programme, Faculty of Biological and Environmental Sciences, University of Helsinki, P.O.Box 65, 00014 Helsinki, Finland

K. Kuoppamäki

Ecosystems and Environment Research Programme, Faculty of Biological and Environmental Sciences, University of Helsinki, Niemenkatu 73, 00014 Lahti, Finland temperature, smelt reached exceptionally high abundance, which led to a significant reduction in cladoceran body size. The density of perch (Perca fluviatilis L.) increased at first, but then decreased when the proportion of smelt and cyprinids increased. Biomasses of Daphnia decreased probably as a result of the disappearance of dark, low-oxygen deep-water refuge against fish predation and low availability of nutritionally high-quality algae. Occasionally filamentous cyanobacteria, such as turbulence tolerant Planktothrix agardhii (Gomont), were abundant, suggesting deteriorated food resources for zooplankton. The responses of food web were controversial with respect to the aim of the management, which was to prevent the occurrence of harmful algal blooms.

Keywords Lake restoration - Hypoxia $\cdot$ Artificial circulation · Hydroacoustics $\cdot$ Diet · Cladocera

\section{Introduction}

Anthropogenic eutrophication of lakes is often manifested as seasonal hypolimnetic oxygen depletion, which may accelerate internal nutrient loading (Schindler, 2006). Severe seasonal anoxia and hypoxia can lead to loss of fauna through habitat compression, emphasising the importance of oxygen for maintaining fish populations (Diaz, 2001). Hypolimnetic oxygen depletion can also intensify trophic 
interactions as fish and their zooplanktonic prey become concentrated in layers above hypoxic waters (Vanderploeg et al., 2009) especially if the euphotic zone expands near or well into the anoxic water layer (Vakkilainen \& Kairesalo, 2005). In such conditions, large cladocerans may become eliminated by fish (Kitchell \& Kitchell, 1980). Oxygen-rich epilimnetic water can be pumped to deep water layers creating an artificial internal circulation in order to manage eutrophic stratified lakes suffering from hypolimnetic anoxia and internal phosphorous load (reviewed in Cooke et al., 2005). Mixing warm surface water to the hypolimnion, however, can result in the warming of deep-water layers and lead to the breakup of summer stratification. Hypolimnetic warming by up to $6{ }^{\circ} \mathrm{C}$ has been observed when mixing surface water to deep water (Gauthier et al., 2014; Sastri et al., 2014). As a result, the loss of the oxygen-low hypolimnetic refuge can cause a major loss of Daphnia populations and a switch to the dominance of smaller cladocerans indicating increased planktivory by larger populations of juvenile warm-water fish species (Gauthier et al., 2014). Since small cladocerans have weaker control on phytoplankton the resultant decrease in herbivory coupled with the increasing release of nutrients from warmer sediments may favour phytoplankton and increase primary production during the mixing of water layers ( $c f$. Gauthier et al., 2014). Fish have been shown to become more dispersed during whole-lake mixing manipulation, likely due to a response to the loss of preferred cold-water habitat (Heald et al., 2017). The negative effects of artificial destratification during summer on cold-water fish species are so obvious that the pumping method has been tested even to eradicate cold-water alien species (Lawson et al., 2015). Thus, the extent of habitat expansion for fish through oxygenation depends also on the availability of water layers with suitable temperature for each species (Aku et al., 1997). The artificial circulation technique is suggested to be most applicable in lakes that are not nutrient-limited and where oxygen depletion is a threat to warm-water fish (Cooke et al., 2005).

Even though hypolimnetic aeration by pumping epilimnetic water to the hypolimnion often does not reduce internal phosphorus load (Cooke et al., 2005) and can have negative effects on cold-water fish and unforeseeable effects on the functioning of food webs, it has been applied as a cost-effective method to increase dissolved oxygen in hypolimnetic water of many eutrophic lakes in Finland.

Lake Vesijärvi has a long history of various management and restoration actions, including also hypolimnetic oxygenation that was, however, not successful in managing the highly eutrophic state of the lake (Keto, 1982). Later, the elimination of cyanobacterial blooms and re-establishment of sustainable fisheries were achieved with a large-scale biomanipulation project in 1989-1993 (Horppila et al., 1998). Intensive trawling of roach (Rutilus rutilus L.) and smelt (Osmerus eperlanus L.) collapsed their populations (Horppila \& Peltonen 1994; Horppila et al., 1996) and perch (Perca fluviatilis L.) became the dominant species in the fish community (Peltonen et al., 1999a). The decreased concentrations of nutrients and chlorophyll $a$, the disappearance of cyanobacterial blooms and increased water clarity were attributed to the reduction of fish-mediated nutrient transfer from benthic and littoral habitats to the pelagic zone (Hansson et al., 1998; Horppila et al., 1998; Kairesalo et al., 1999). The smelt population recovered gradually, and it has been the dominant species in the pelagic area. The size of the population, however, has fluctuated widely and collapsed temporarily in the warm summer of 2002 (Ruuhijärvi et al., 2005), which was reflected in slightly increased cladoceran body size (Nykänen et al., 2010; Vakkilainen \& Kairesalo, 2005). The clear-water state of 1990 's gradually turned into lower water quality with occasional cyanobacterial blooms, decreased water clarity and hypolimnetic hypoxia during summer stratification (Anttila et al., 2013). This suggests that external non-point source loading to the lake is still too high, beyond the threshold for high internal loading (cf. Andersen et al., 2008) and originates from e.g., the extensive urban areas around the southernmost basin (Fig. 1; see also Valtanen et al., 2014). Despite the problems with water quality and algal blooms, the fishery of the lake improved and the catches of predatory fish, especially perch and pikeperch (Sander lucioperca L.), increased (Ruuhijärvi et al., 2005). Continuous yearly management fishing and regulations of fishing practices in Lake Vesijärvi were designed to maintain abundant stocks of piscivorous fish, and thus keeping the stocks of planktivorous fish at a moderate level.

In the present work, we studied the responses of the most abundant pelagic fish stocks and zooplankton 
community to hypolimnetic aeration and hypothesised that (1) the warming of the hypolimnion in summer would collapse cold-water fish populations, essentially the smelt population and (2) the vacant pelagic niche of smelt would be filled by other planktivores, either previously abundant roach or perch, which increased along with the biomanipulation. Furthermore, we hypothesised that (3) the collapse of the smelt population will result in lower predation pressure on zooplankton and thus increase the body size of cladocerans, at least until smelt becomes replaced by another planktivorous fish species, tolerant to high temperature-leading to the decrease of large cladocerans due to the lack of their hypolimnetic refuge. We hypothesised that (4) a decrease of large-bodied cladoceran herbivores with increased zooplanktivory cascades to higher phytoplankton biomass and vice versa. Because smelt is an important food source for predatory fish, pikeperch and large perch, we also hypothesised (5) a decline in their abundance following the collapse of smelt.

\section{Materials and methods}

Study site

The southernmost basin of Lake Vesijärvi, located in southern Finland (Fig. 1), has been treated with 9 Mixox pumps during stratification periods in summer and winter since 2010 (Salmi et al., 2014; Niemistö et al., 2016). Maximum water volume pumped to the hypolimnion with nine pumps was $8000 \mathrm{l} \mathrm{s}^{-1}$ and estimated transport of dissolved oxygen was $6500 \mathrm{~kg}$ $\mathrm{d}^{-1}$, respectively. The implementation of the method was based on the knowledge that hypolimnetic anoxia increases internal phosphorous load and enhances reeutrophication of the lake. Therefore, preventing hypolimnetic oxygen depletion by mixing the water column was expected to reduce internal phosphorus loading, occasional cyanobacterial blooms and rehabilitate the lake.

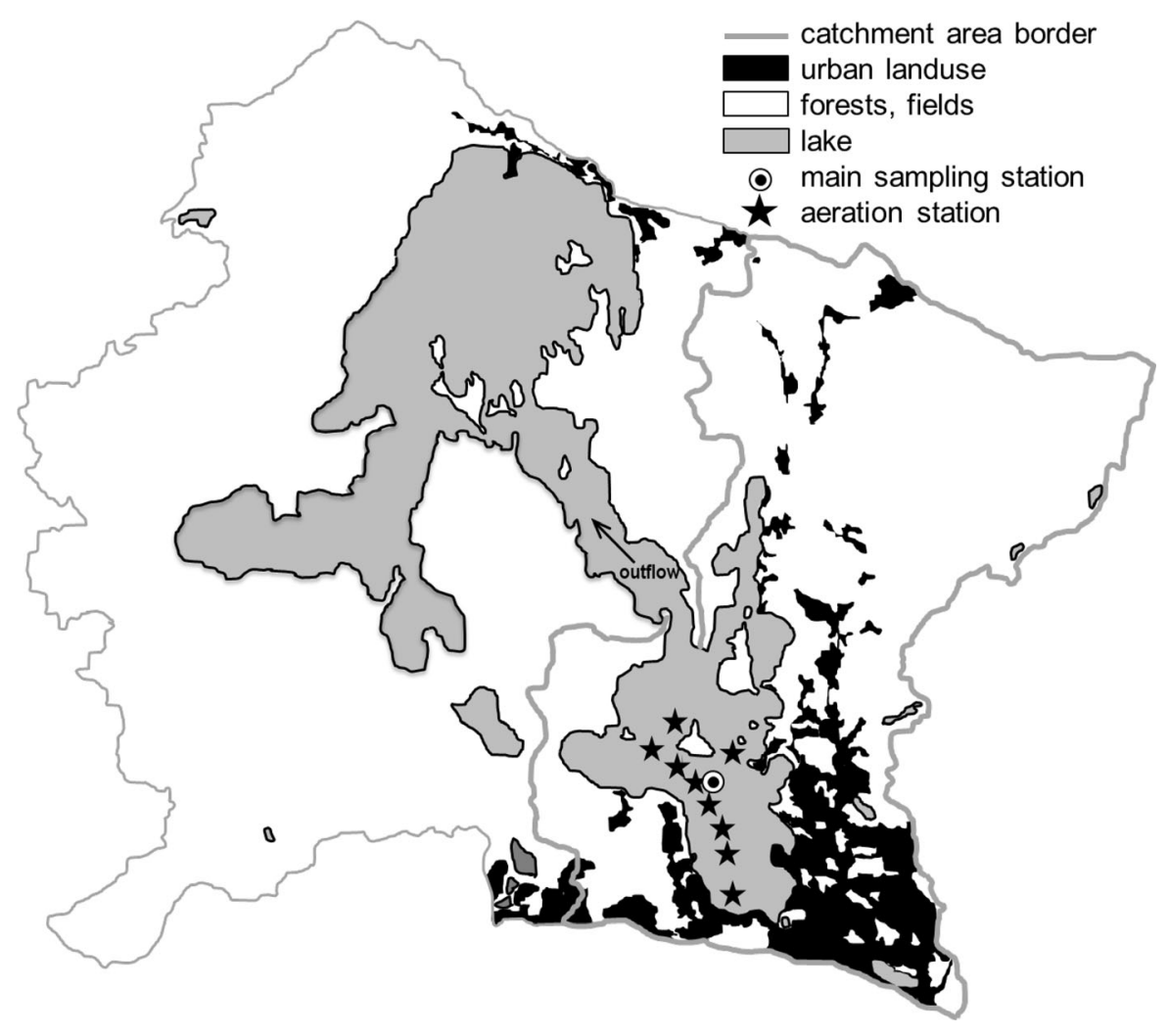

Fig. 1 The map of Lake Vesijärvi with the catchment area. The study area was the southernmost basin, called Enonselkä, and the map shows the locations of aerators and the station where samples were taken for zooplankton and chlorophyll a, together with measurements of oxygen and temperature profiles 
Study strategy

The study of the food web of the Enonselkä basin of Lake Vesijärvi started in 2009, 1 year before hypolimnetic aeration. However, in order to understand the development of the pelagial community and water quality during the aeration period of 2010-2017, antecedent monitoring data since 2000 , collected by University of Helsinki, supplemented by data on nutrient concentrations and phytoplankton obtained from the database of the Finnish Environmental Information Portal, were also included in this paper. Project funding did not allow the measurement of all parameters every year.

Physical and chemical properties of water

Water temperature and oxygen concentration profiles in the deepest part of the Enonselkä basin were measured at $1-\mathrm{m}$ intervals from the surface to the bottom by using the optical YSI proODO instrument. Sampling was done fortnightly from May-June to October in 2000-2017 except in 2014. Composite water samples for chlorophyll $a$ (Chl $a$ ) were taken from $0-5 \mathrm{~m}$ depth and measured in the laboratory spectrophotometrically after extraction into ethanol. Results on temperature, dissolved oxygen and Chl $a$ were supplemented by those in the database of the Finnish Environmental Information Portal. The same source was used to get data on total phosphorus concentrations that have been measured from samples taken at $1 \mathrm{~m}$ depth and near the bottom at $29 \mathrm{~m}$ depth.

\section{Zooplankton analyses}

Zooplankton sampling was carried out in the deepest part $(30 \mathrm{~m})$ of the Enonselkä Basin fortnightly during the growing season from late May or early June to October in 2000-2017 (no sampling in 2014). Samples were taken with a Limnos tube sampler (length $1 \mathrm{~m}$, volume 6.9 1) from the entire water column and pooled into $5 \mathrm{~m}$ samples. After filtering through a $50-\mu \mathrm{m}$ mesh, samples were preserved in $70 \%$ ethanol. Samples from 2001-2006, 2009, 2011, 2013, and 2015-2017 have been analysed. Upon analysis, subsamples were pooled into composite samples from epilimnion (0-10 m) and hypolimnion (10-30 m). Zooplankton identification, enumeration and length measurements were taken with an inverted microscope at $\times 100$ and $\times 40$ magnifications. Leptodora kindtii (Focke, 1844) were counted and measured by using a dissecting microscope. At least 100 individuals of the most numerous species were counted and the lengths of 30 individuals of the most abundant cladoceran species in each sample were measured, while all individuals of the less abundant species were measured. Length measurement was taken from top of the head or, in daphnids from top of the eye, to the base of the carapax tail. Three individuals of each copepodid stage were measured from top of head to the base of furca. Species-specific biomass estimates were obtained as described in Vakkilainen et al. (2004).

Hydroacoustic fish density and biomass estimation

Pelagic fish density and biomass were estimated with hydroacoustics and simultaneous trawling on two occasions, in the beginning of July and at the end of August, during years 2009 and 2011-2017. The first occasion represents the state of pelagic fish assemblage during the 'midsummer' biomass peak of zooplankton. At that time, the very small-sized [15-35 mm total length (TL)] young-of-the-year fish strongly prefer the near-surface layer (blind zone); therefore, hydroacoustic estimates represent the density and biomass of older fish. The second occasion represents the state of fish assemblage during the possible hypolimnetic oxygen depletion near the end of summer temperature stratification. During that time, the young-of-the-year fish have achieved detectable size (length range 30-70 $\mathrm{mm}$ TL), may inhabit the whole water column and prey on cladoceran zooplankton.

Hydroacoustic sampling was done during the day along 6-10 equidistant transects (from north to south) at intervals of 500-1000 m covering the areas $>6 \mathrm{~m}$ deep of the Enonselkä basin. The location of the first transect was randomized. In order to determine species composition and fish length distribution, 3-8 trawl hauls were conducted in the layers where fish density was highest during each survey. In addition, to exclude the possibility that the surface 'blind' zone of echo sounder would have been a considerable source of bias, 1-2 surface trawl hauls were conducted. These swept area estimates, however, revealed that the fish density in the blind zone was negligible $(<2.5 \%$ of the acoustic density estimate) in all study occasions. 
Echo soundings were done with a SIMRAD EY500 echo sounder equipped with a split-beam transducer ES120-7C (operating frequency $120 \mathrm{kHz}$ and beam opening angle $7^{\circ}$ at $-3 \mathrm{~dB}$ level). Pulse duration was set to $0.3 \mathrm{~ms}$, pulse interval to 'minimum value' and target strength threshold to $-65 \mathrm{~dB}$. The transducer was calibrated using a standard copper sphere (target strength $-40.4 \mathrm{~dB}$ ) with SIMRAD LOBE-program. The small pelagic trawl used had a height of $3.5 \mathrm{~m}$ and width of $8 \mathrm{~m}$, and cod-end mesh size $3 \mathrm{~mm}$. The trawl was towed with a 370-hp vessel and the speed of trawling was ca. $3 \mathrm{~km} \mathrm{~h}^{-1}$. From each haul, a random sample of 5-20 kg was taken for species composition and length measurements.

Hydroacoustic fish density estimates were computed by echo integration (Simmonds \& MacLennan, 2005). The analyses extended from $3 \mathrm{~m}$ depth to $0.5 \mathrm{~m}$ above lake bottom. The total backscattering coefficient ( $s_{a}$, MacLennan et al., 2002) was calculated by EP500 software and the mean cross-section $(\sigma)$ was determined either (1) by using the length distribution of trawl catches and a relationship between fish length and target strength (Peltonen et al., 2006; Malinen, 2018), or (2) by using the target strength distribution obtained with the echo sounder. These methods are complementary: the method (2) is superior at low fish densities (Kocovsky et al., 2013) but produces biased results at high densities (Sawada et al., 1993). At very high densities only the method (1) is appropriate. The fish density was computed as $\mathrm{s}_{\mathrm{a}} / \sigma$ (Simmonds \& MacLennan, 2005). The methane ebullition from sediment, which occasionally biased $\mathrm{s}_{\mathrm{a}}$-value in the 1990s (Peltonen et al., 1999b), was almost negligible in the present study. Only some bubble trails were observed, and they were readily screened out manually. The fish density was divided into species-specific estimates based on species distributions of trawl catches. These were converted to biomass estimates based on the mean weights of each species. The average density and biomass in the study area were computed using transect lengths as weights (Shotton \& Bazigos, 1984) and their 95\% confidence limits were estimated based on Poisson distribution (Jolly \& Hampton, 1990).

Fish community structure

The structure of fish community of the Enonselkä basin ( $>1.5 \mathrm{~m}$ deep areas) was studied annually by stratified random sampling with NORDIC multimesh gill nets (Appelberg et al., 1995; Olin et al., 2002) in 2009-2017. The NORDIC gill net is $1.5 \mathrm{~m}$ high, $30 \mathrm{~m}$ long and it consists of 12 panels ( $2.5 \mathrm{~m}$ each) having mesh sizes 5, 6.25, 8, 10, 12.5, 15.5, 19.5, 24, 29, 35, 43, and $55 \mathrm{~mm}$ (bar length). The sampling took place in July-August for four nights. The Enonselkä basin was divided in four depth zones and the total sampling effort was 60 net-nights every year. For details of sampling and measuring the fish catch see Olin et al. (2002). Catch per unit effort (CPUE, kg net ${ }^{-1}$ night $^{-1}$ and NPUE, number of fish net ${ }^{-1}$ night $^{-1}$ ) was used as index of fish abundance. CPUE and NPUE were calculated as arithmetic means of the 60 replicates of a sampling year.

\section{Diet analyses}

Diet samples of the most abundant planktivores (smelt, perch, and roach) were collected from the catch of trawl hauls made during hydroacoustic surveys in years 2009, 2011, 2013, and 2015. In cases, when the diet sample of certain species from trawl catch was smaller than 20 individuals, it was supplemented with samples from simultaneous gill net fishing having about $4 \mathrm{~h}$ soak time. If the number of individuals remained below 20 , the results were omitted.

The stomach contents of smelt and perch were analysed using a volumetric proportion method (Hynes, 1950; Windell, 1971). Because cyprinids do not have a distinct stomach, the proportions of ingested food items by roach were analysed from the anterior third of gut (Vøllestad, 1985; Rask, 1989). Since perch larger than $15 \mathrm{~cm}$ feed mostly fish in the Enonselkä basin (Horppila et al., 2000), they were dropped from the present diet analysis. The length distributions of young-of-the-year smelt did not overlap with those of older smelt and the diet composition for these groups are presented separately. The diet analyses of youngof-the-year smelt caught in midsummer were difficult and time-consuming due to their small size (mean length 20-30 mm), and they were done only in year 2015 .

Data analyses

Water temperatures, oxygen concentrations and zooplankton biomasses measured during the years of 
hypolimnetic aeration were compared to those measured before aeration by using paired samples t-test. If data was not normally distributed even after lntransformation, we used related samples Wilcoxon signed rank test. Three measurements per year (between mid-July and mid-August) were used, i.e. $n=18$ before aeration and $n=18$ during aeration. Density-weighed cladoceran body size before and after the appearance of exceptionally high populations of smelt was tested accordingly but by using 3 years ( 3 dates per year in midsummer and 3 dates per year in late summer), i.e. $n=9$ before and $n=9$ after the proliferation of smelt. All data analyses were done using IBM SPSS Statistics version 25.

\section{Results}

Physical and chemical properties of the lake

Hypolimnetic temperature at the end of summer increased significantly after 2009, when epilimnetic water was pumped into the hypolimnion, compared to the previous years without hypolimnetic aeration (paired samples t-test; $t=-7.737, P<0.001$; Fig. 2). In 2013, however, temperature was much lower, since after a very warm spring (air temperature in May 3.1 ${ }^{\circ} \mathrm{C}$ higher than $1981-2010$ average) the water column became strongly stratified in early summer with a steep thermocline at 7-8 $\mathrm{m}$ with cool $\left(<10^{\circ} \mathrm{C}\right)$ oxygen-rich $\left(>4.5 \mathrm{mg}^{-1}\right)$ water below until mid-July. This was the reason why lake managers turned the pumps on only on the 12th July, 1 month later than in the other years. Pumping was delayed also in 2015 and 2016 due to good oxygen conditions in the hypolimnion. The first two summers of aeration were warm $\left(2{ }^{\circ} \mathrm{C}\right.$ warmer than $1981-2010$ average $)$ and characterised by low hypolimnetic oxygen concentrations (Fig. 2). At its worst, hypoxic ( $\left.\leq 2 \mathrm{mg} \mathrm{O}_{2} \mathrm{l}^{-1}\right)$ water layer extended from the $30 \mathrm{~m}$ deep up to the depth of 7-10 m, where also water temperature was $\geq 18{ }^{\circ} \mathrm{C}$ (Fig. 3). Thus, hypolimnetic aeration resulted in an unfavourable environment for coldwater fish, i.e. predominantly smelt. Thereafter, the volume and duration of hypolimnetic hypoxia decreased, while water having temperature of $\geq 18{ }^{\circ} \mathrm{C}$ often extended deep in the water column, especially in August 2015-2017, when this warm water reached down to 20-30 $\mathrm{m}$ depth (Fig. 3).
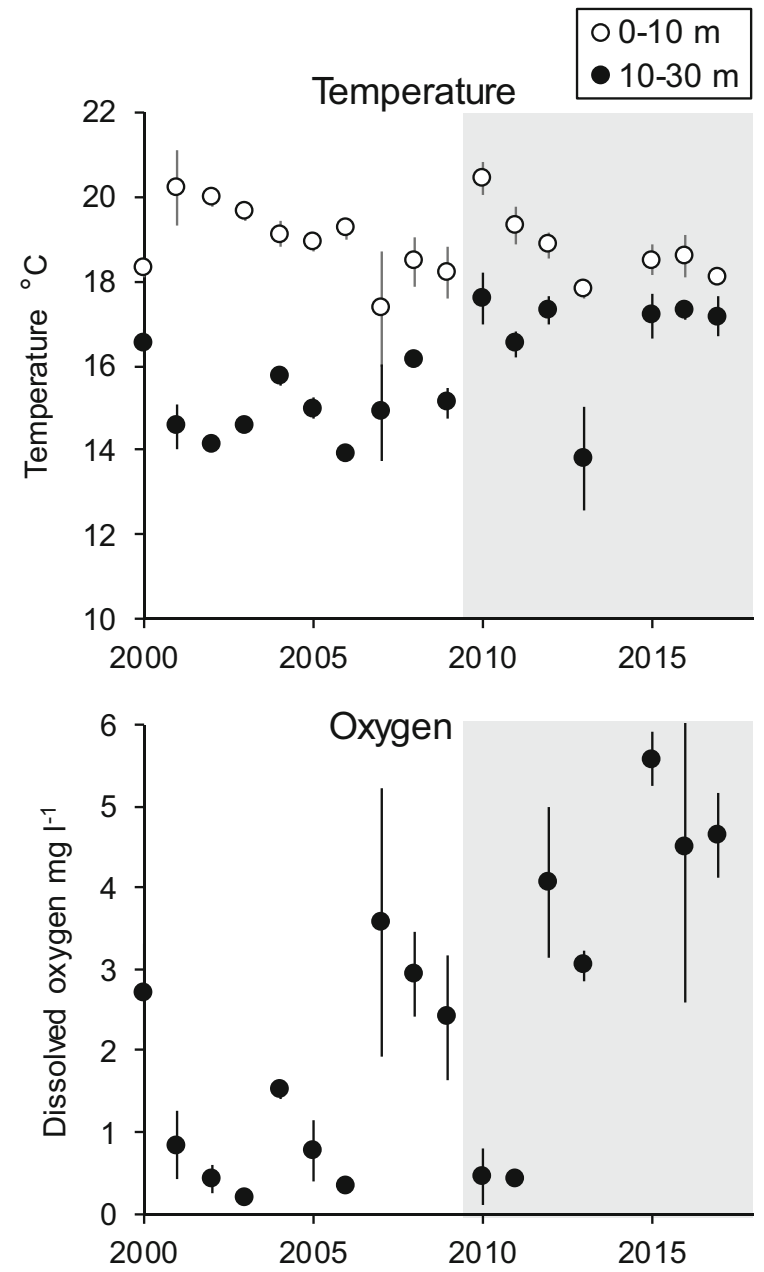

Fig. 2 Volume-weighted mean ( \pm SE) epilimnetic $(0-10 \mathrm{~m})$ and hypolimnetic (10-30 m) temperature (top) and hypolimnetic dissolved oxygen concentration (down) from mid-July until mid-August in 2000-2017. The grey bars indicate the period of hypolimnetic aeration

Oxygen concentrations in hypolimnion did not increase significantly during the aeration period compared to the previous period of equal length (Wilcoxon signed rank test $P=0.157)$. Concentrations of total phosphorus (TP) neither near the surface (1 m depth) nor near the bottom (29 $\mathrm{m}$ depth) have decreased during the period of hypolimnetic aeration and recently a slightly increasing trend has been observed especially in surface water (Fig. 4). Algal biomasses, measured as $\mathrm{Chl} a$ concentration, have remained at the same level (ca. $10 \mu \mathrm{g} \mathrm{l}^{-1}$ ) during the study period except for high algal biomasses in 2009, when cyanobacteria proliferated at the end of summer 


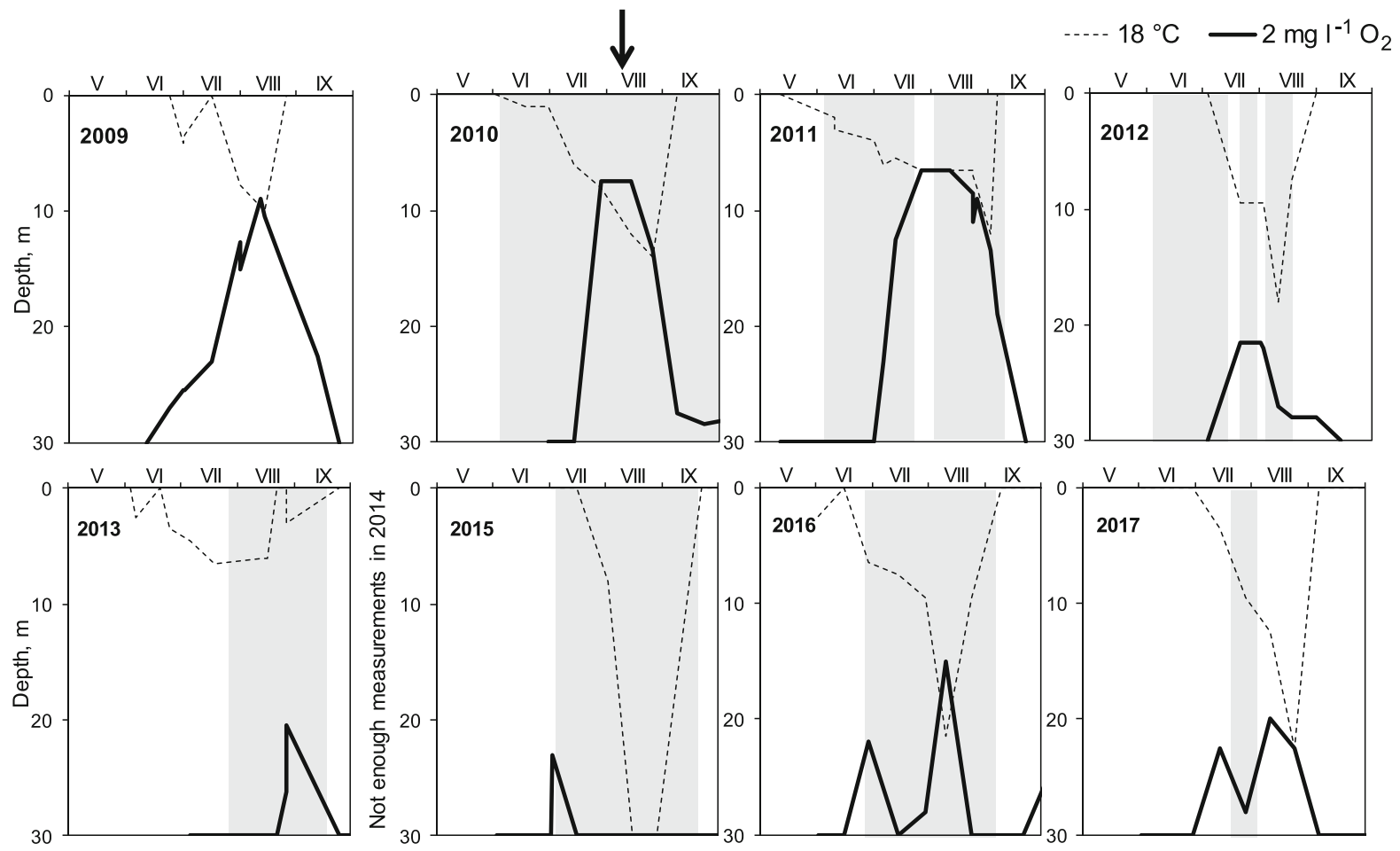

Fig. 3 The isopleths for tolerable temperature $\left(18{ }^{\circ} \mathrm{C}\right.$ according to Lantry \& Stewart, 1993) and dissolved oxygen concentration ( $2 \mathrm{mg}^{-1}$ according to Keskinen et al., 2012) for smelt during May-June to October in 2009-2013 and 2015-2017. The arrow indicates the collapse of the smelt population in 2010 and grey

(Fig. 4). A similar cyanobacterial peak occurred also in 2002 but was not detected as elevated levels of $\mathrm{Chl}$ a. Cyanobacteria were abundant also in 2016. Planktothrix agardhii (Gomont) was among the dominating species.

\section{Zooplankton}

The midsummer cladoceran biomass peak consisted of Bosmina [B. crassicornis (Liljeborg, 1887) and $B$. longirostris (O. F. Müller, 1785)] and Daphnia [D. cucullata (G. O. Sars, 1862) D. cristata (G. O. Sars, 1861) and D. longiremis (G. O. Sars, 1862)]. Another lower peak often occurred in August and early September and was built up mainly by $D$. cucullata (G. O. Sars, 1862), Limnosida frontosa (G. O. Sars, 1862), Diaphanosoma brachyurum (Liévin, 1848) and Chydorus sphaericus (O.F. Müller, 1776). Especially midsummer biomasses of Daphnia experienced a drop from early 2000s' to 2009 and thereafter remained at a lower level (Fig. 5). Also, Bosmina biomasses areas indicate when hypolimnetic aeration was in operation. Zooplankton sampling and, thus, the concomitant 1-m interval measurements of temperature and oxygen were not done in 2014 and therefore there are not enough data to calculate isopleths (aeration was done from 4th June until 25th September 2014)

declined in early 2000s' and thereafter have varied without a trend. Epilimnetic predatory cladoceran Leptodora kindtii (Focke, 1844) increased in biomass after the start of aeration, though temporal variation was high (Fig. 5). Biomasses of copepods (predominantly Eudiaptomus gracilis (Sars, 1863) and Cyclopoida in the epilimnion, Limnocalanus macrurus (G. O. Sars, 1863) in the hypolimnion) differed very little between midsummer and late summer. They increased in early 2000s' and, like Daphnia, declined strongly in 2009 but have thereafter been slightly increasing (Fig. 5). Biomasses of Daphnia and total herbivorous cladocerans have been $50 \%$ and $74 \%$ lower during hypolimnetic aeration compared to the preceding period. However, changes in zooplankton biomass were not statistically significant probably as a result of temporal variation.

Body size of herbivorous cladocerans consistently increased from 2009 until 2013 both in midsummer and late summer, while a major reduction occurred in 2015 (Fig. 5) after the appearance of an exceptionally 


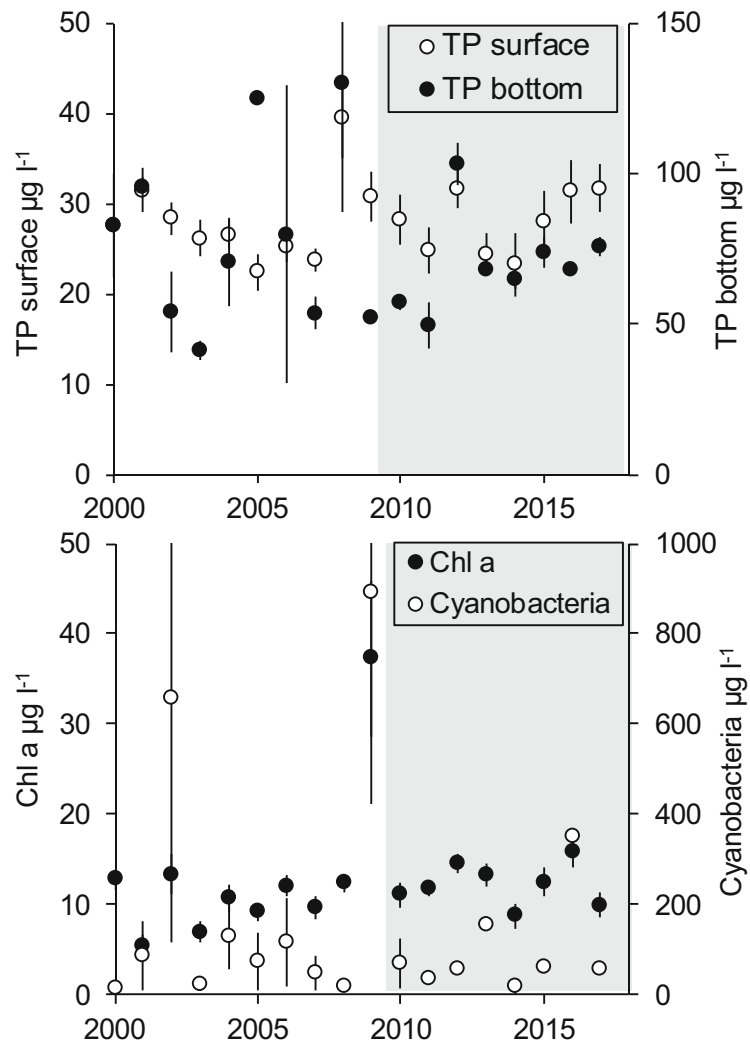

Fig. 4 The mean $( \pm$ SE) concentrations of total phosphorus (TP) in water near the surface $(1 \mathrm{~m})$ and near the bottom $(29 \mathrm{~m})$ of the lake (top panel) and concentrations of surface water chlorophyll $a(\mathrm{Chl} a)$ and the biomass of cyanobacteria (the panel below) in July-August during the 2000s'. The grey bars indicate the period of hypolimnetic aeration

strong year-class of smelt. As small-bodied bosminids were abundant in midsummer, they decreased the mean body size of cladoceran community. Late summer cladocerans were $78 \%$ smaller during exceptionally dense populations of smelt compared to preceding period with the collapse of smelt (paired samples t-test; $t=3.393, P=0.009$ ).

Fish populations

Before the onset of aeration, fish density was dominated by smelt, while fish biomass consisted mostly of roach, bream (Abramis brama L.) and pikeperch (Fig. 6). Between autumn 2009 and midsummer $2011,>99 \%$ of the smelt stock disappeared. The collapse was statistically significant $(P<0.01)$, because $95 \%$ confidence limits of density estimates for July 2011-July 2012 did not overlap with those for
2009 (Austin \& Hux, 2002). The collapse happened most likely during late summer 2010, when a suitable water layer for smelt disappeared for 3 weeks (Fig. 3). The catches of smelt in NORDIC gill nets were almost equal in 2009 and 2010 but very low in 2011 (Fig. 10), suggesting that the smelt stock collapsed at the end of sampling period in JulyAugust 2010 at the earliest.

The lowest smelt density (4 ind. $\mathrm{ha}^{-1}$ ) was observed in late August 2011. At that time, 166 out of all captured 167 specimens were young-of-the-year smelt. They were also smaller (mean TL $39 \mathrm{~mm}$ ) than young-of-the-year in any other years (mean TL 55-62 mm) (t-test, $P<0.01)$. However, the smelt population did not totally disappear but started gradually to produce stronger and stronger year-classes when oxygen depletion diminished (Figs. 2 and 3). During the years of recovery, the population in late August was much more strongly dominated by youngof-the-year fish than in year 2009 (Fig. 7) and earlier (unpublished data and Horppila et al., 1996). This implies that either the natural mortality or migration to other basins must have been exceptionally high. During years 2013-2017, the smelt population size in July was, on average, only $18 \%$ of the population size in August of the preceding year. In 2015, extremely strong year-class of smelt appeared, resulting in the density of ca. 140000 ind. ha ${ }^{-1}$ in late August 2015, which is more than fivefold compared with earlier density estimates (Jurvelius \& Sammalkorpi, 1995; Peltonen et al., 1999b; Ruuhijärvi et al., 2005). Because year-classes born in 2016 and 2017 were also larger than average, smelt biomass stayed exceptionally high, around $100 \mathrm{~kg} \mathrm{ha}^{-1}$, during the years 2015-2017 (Fig. 6). Interestingly, smelt stock did not collapse in summer 2016, when temperature and oxygen were temporarily 'intolerable' in the beginning of August (Fig. 3).

After the smelt collapse, during July 2011-July 2012, the pelagic fish density was only 1300-1900 ind. $\mathrm{ha}^{-1}$. Perch was the only species that increased in density and biomass in the pelagic area during summers with the sparse smelt population (Figs. 6 and 8). This slight perch invasion proved to be only temporary, as pelagic perch density decreased again when the 1st abundant year-class of smelt appeared in late summer 2012. The density of roach, another potentially invasive species in pelagic areas, remained at a low level during the whole study period (Fig. 8). 

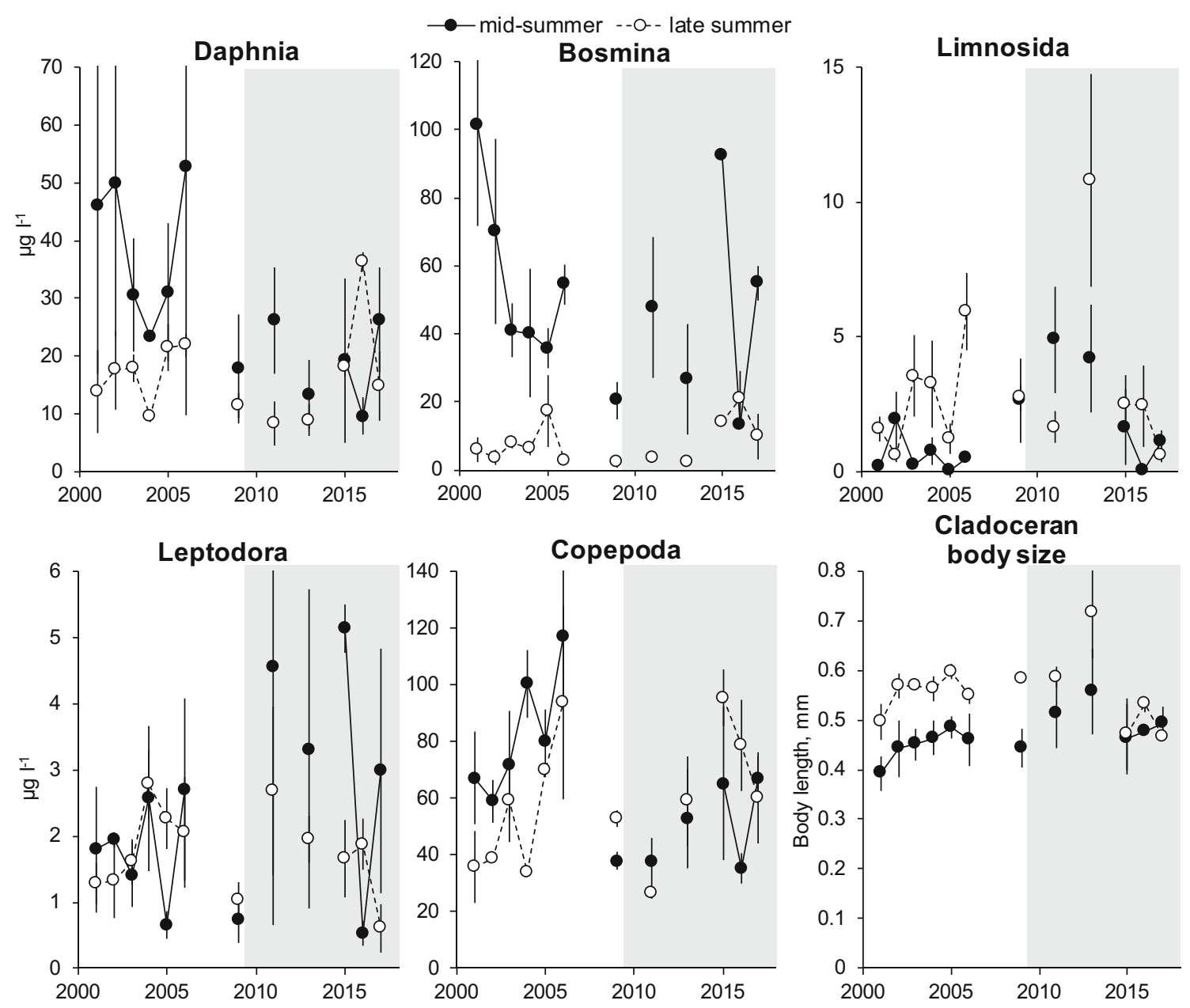

Fig. 5 Average ( \pm SE) volume-weighed biomass of Daphnia spp., Bosmina spp., Limnosida frontosa, Leptodora kindtii and Copepoda as well as the density-weighted average ( \pm SE) body

There were no observable trends either in the densities of other species. Hydroacoustic biomass estimates of both roach and bream fluctuated widely but had a different pattern: roach biomass was moderate in the mid-summer 2009, 2011 and 2015, while bream biomass was high in late summer of 2009 and 2011.

The index of fish abundance as CPUE of NORDIC gill nets varied annually between 1.59 and $2.83 \mathrm{~kg}$ and 69 and 131 fish, respectively (Fig. 9). Catches (kg) decreased from 2011 to 2017. The three most abundant species, perch, smelt and roach showed different changes in their abundance (Fig. 10). Perch were usually the most abundant fish. Perch CPUE peaked in $2011(1.53 \mathrm{~kg})$, declined in 2013-2016 and reached lowest value $(0.56 \mathrm{~kg})$ in 2016 . Roach catches were size of herbivorous cladocerans during midsummer $(n=3)$ and late summer $(n=3)$ in the 2000s'. The grey bars indicate the period of hypolimnetic aeration

about half less than those of perch during 2009-2014 but the weight CPUEs of perch and roach were rather equal in 2015-2017. The CPUE of smelt showed the same trend in abundance and biomass detected with hydroacoustics: A collapse of the stock in 2011, a gradual recovery in 2012-2014 and a very high abundance in 2015-2017. When comparing the CPUE of smelt to other fish species, the low catchability of smelt with NORDIC gill nets must be kept in mind (Olin \& Malinen, 2003; Olin et al., 2009).

The catches of the main fish groups in NORDIC nets, percids [perch, pikeperch and ruffe (Gymnocephalus cernua L.)] and cyprinids (Fig. 9) were characterized by the dominance of percids in 2009-2014. Thereafter, the share of cyprinids and 
A

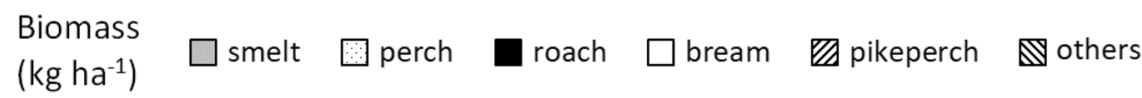

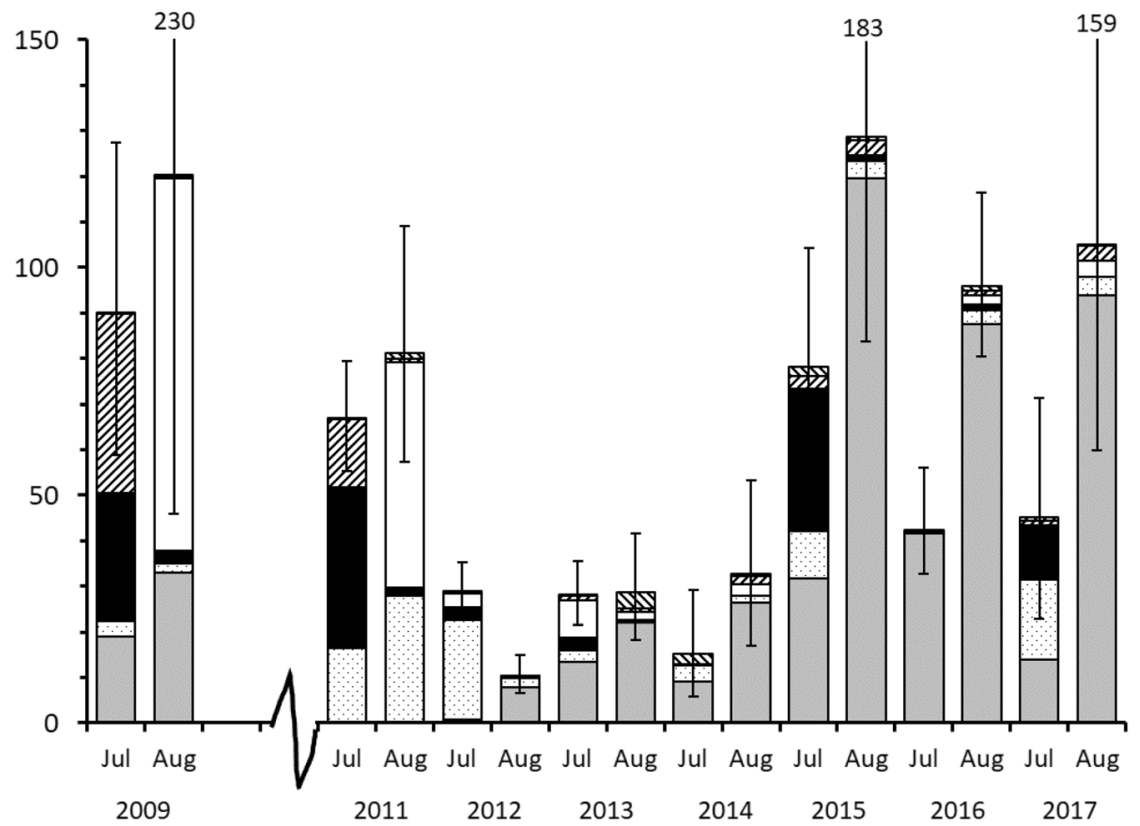

B

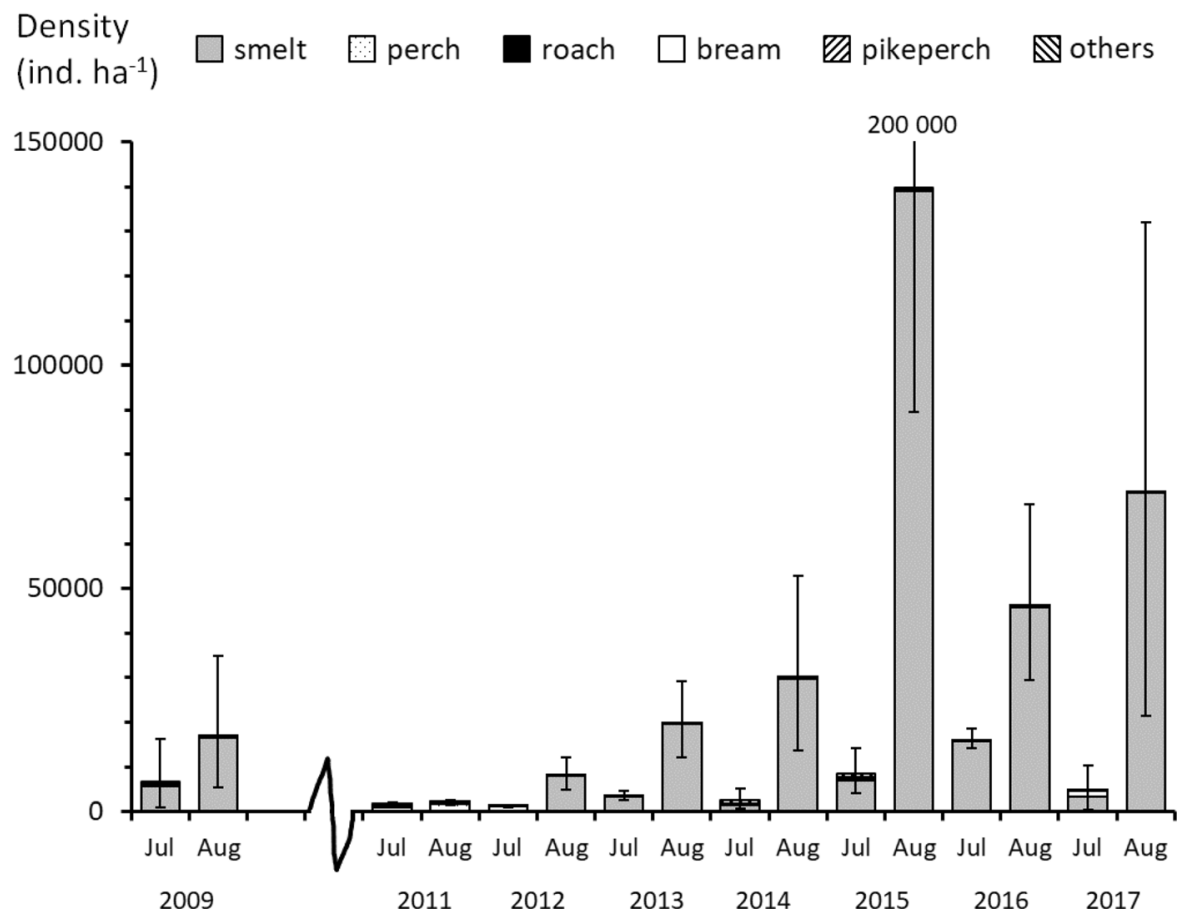

Fig. 6 Hydroacoustic fish biomass (A) and density (B) estimates with 95\% confidence limits for $>6$ m deep areas of the Enonselkä basin in 2009 and 2011-2017 
Fig. 7 The lengthdistribution (total length) of smelt in the trawl catches in late August from 9-15 m depth (the layer which typically had the highest smelt density) in 2009 and 2012-2017. In 2011, only one smelt was caught from that depth and panel represents the distribution of all captured smelt individuals from the different depths (diagonal rasters). Numbers of measured fishes are also mentioned
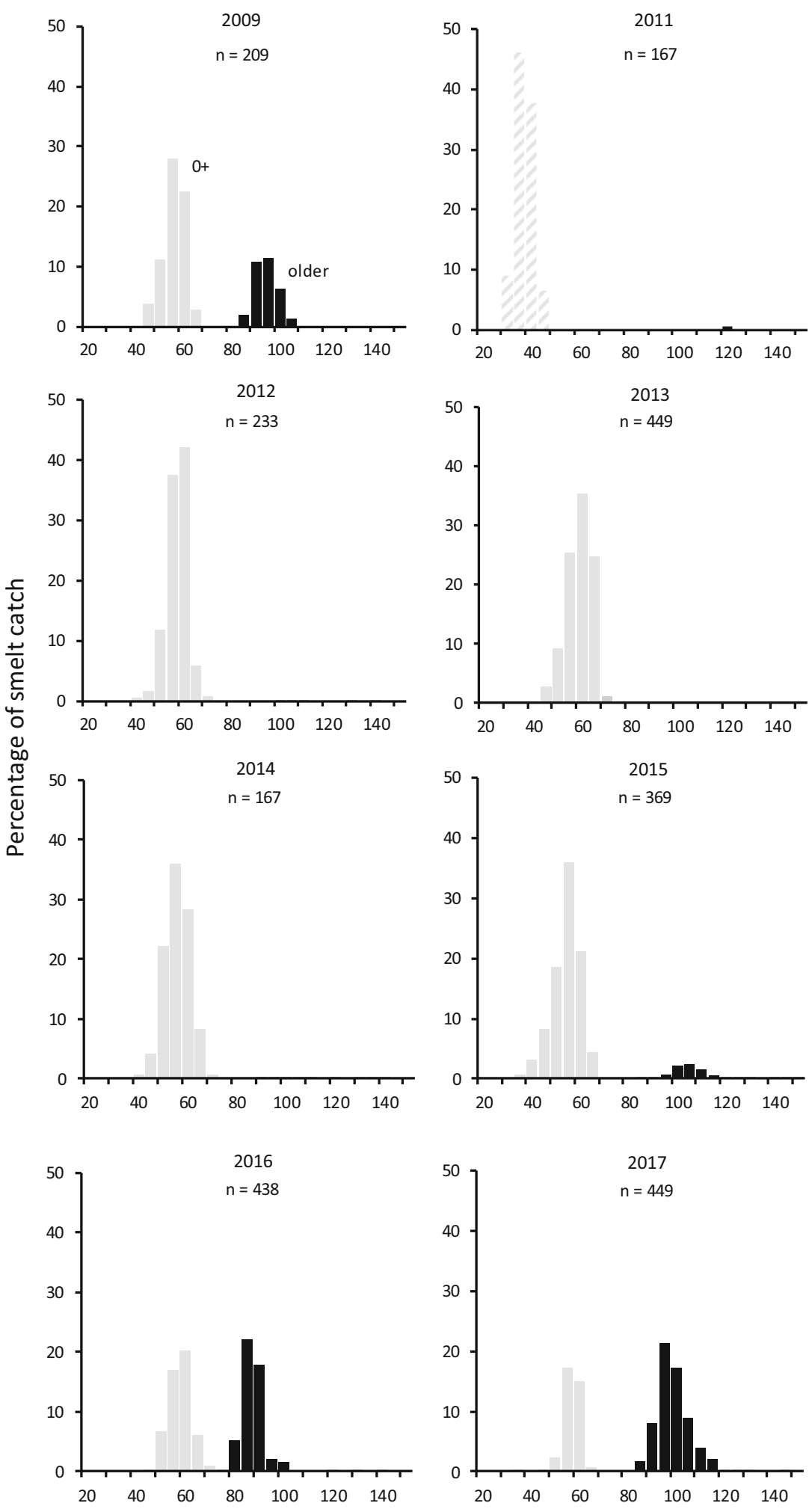

Length $(\mathrm{mm})$ 


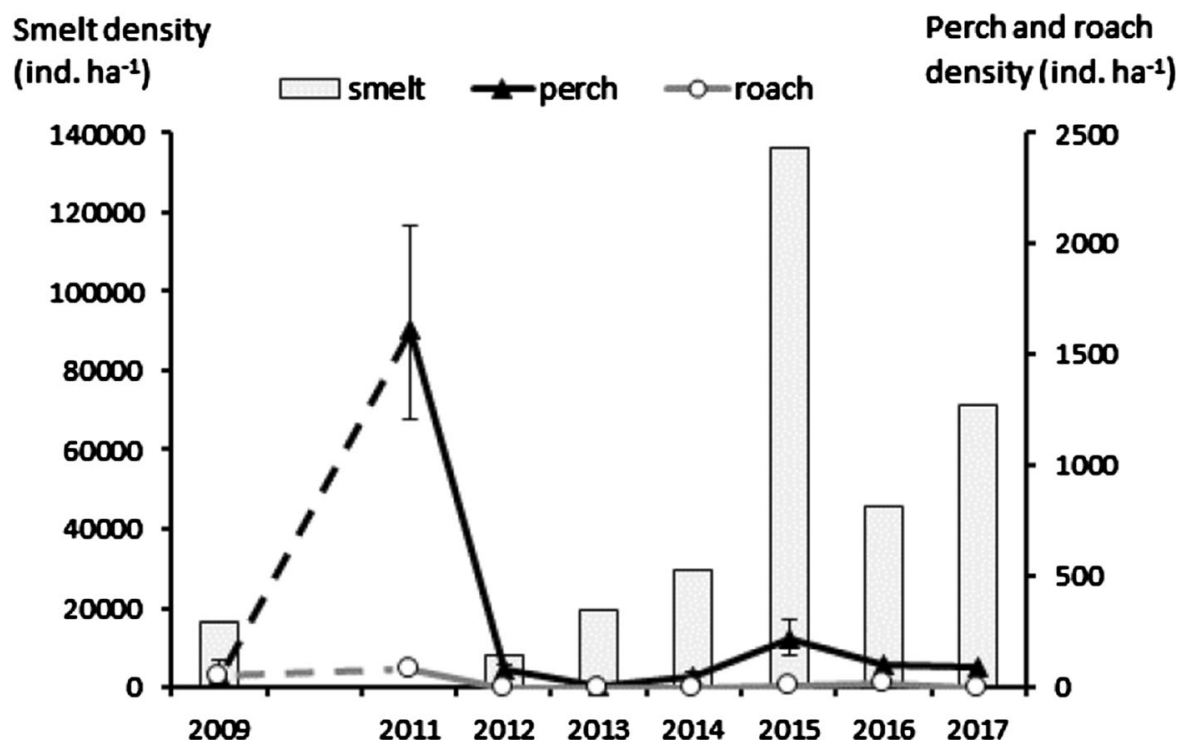

Fig. 8 The hydroacoustic density of smelt, perch and roach in late August during years 2009 and 2011-2017. The 95\% confidence limits for perch density estimates are also presented

Fig. 9 The average total fish NPUE + S.E. (top) and CPUE + S.E. (down) of NORDIC gill nets divided in the catch of percids (perch, pikeperch and ruffe), cyprinids and other fish (mainly smelt) (bars) as well as the NPUE and CPUE of piscivorous fish $(>15 \mathrm{~cm}$ perch, pikeperch and pike) (dots) in the Enonselkä basin in 2009-2017
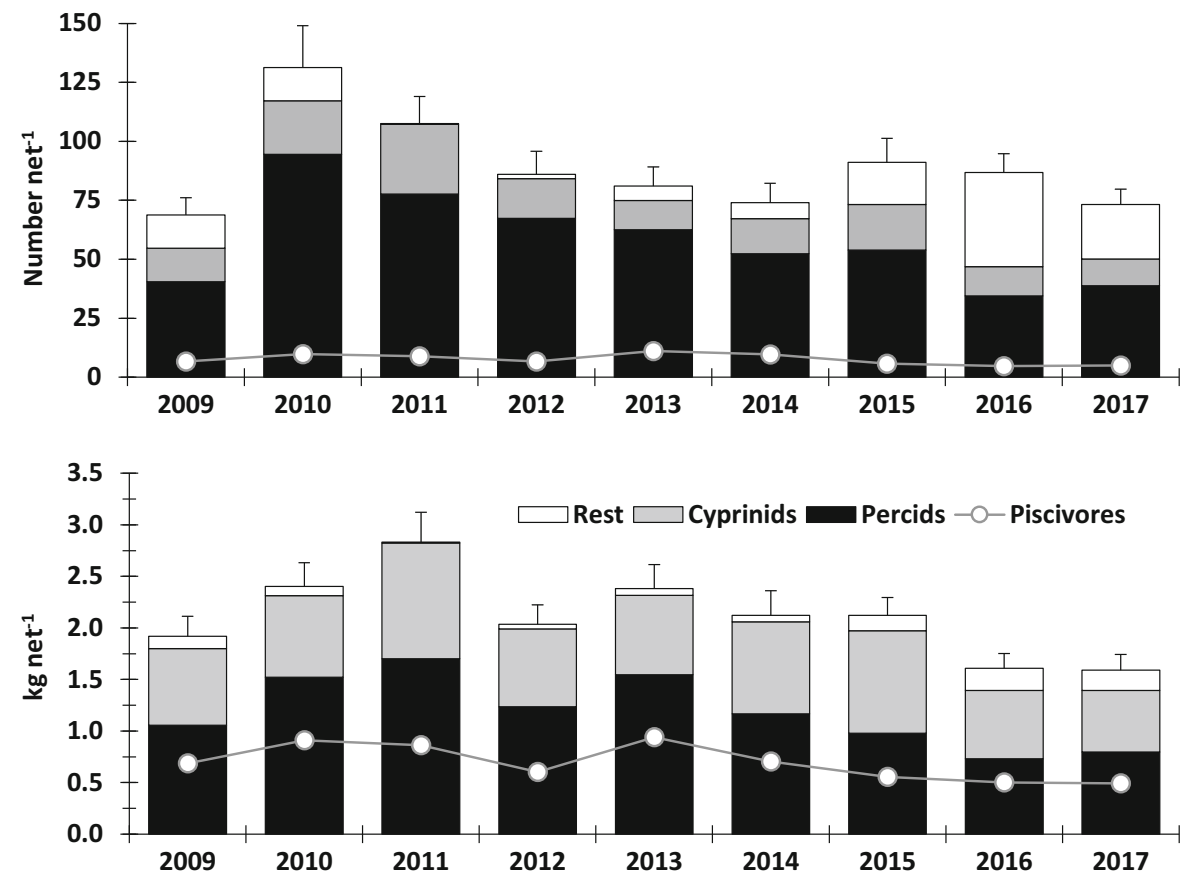

other fish, mainly smelt in the catches, increased. The NORDIC net catches of piscivorous fish, mainly $>$ $15 \mathrm{~cm}$ perch and pikeperch, were in a high level (0.60-0.94 kg net $\left.{ }^{-1}\right)$ in 2009-2014 but a decline could be observed in 2015-2017, with catches of 0.56-0.49 kg net ${ }^{-1}$ (Fig. 9).
Diet of fish

The diet of all putative planktivores, smelt, small perch and roach consisted mainly of zooplankton (Figs. 11 and 12). However, there were large differences in prey selectivity between species. Young-of- 
Fig. 10 NPUEs (+ S.E.) (top) and CPUEs (+ S.E.) (down) of perch, pikeperch, smelt and roach in NORDIC gill nets in the Enonselkä basin in 2009-2017
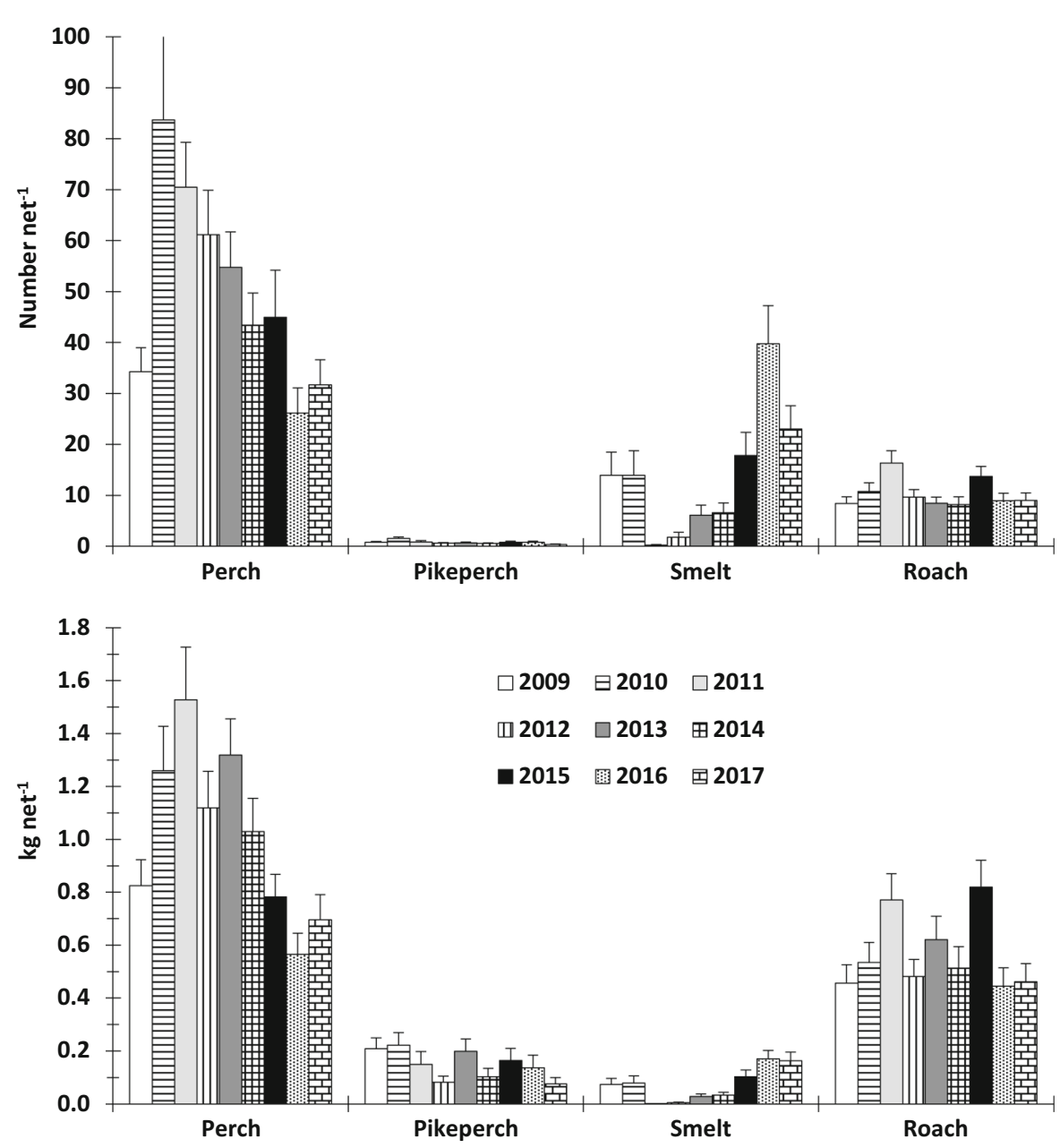

the-year smelt fed mostly on copepods (50-65\% of stomach content) but utilized also cladocerans Daphnia, Limnosida and Bosmina depending on sampling occasion. In the diet of older smelt, herbivorous cladoceran zooplankton were more important prey than copepods, especially in July during the midsummer peak of cladocerans (Figs. 5 and 11). Daphnia and Bosmina were the most important cladocerans in the diet of older smelt. Small perch $(<15 \mathrm{~cm})$ fed mainly on cladocerans, but the proportion of predatory Leptodora was even higher than that of herbivorous cladocerans (mostly Daphnia, Limnosida and Bosmina) in 4 out of 7 studied occasions (Fig. 12). Perch preyed also on copepods but clearly less than smelt. In addition, the analyses revealed that relatively small perch $(<15 \mathrm{~cm})$ are capable to feed fish, as over $50 \%$ of their diet consisted of young-of-the-year smelt that was exceptionally abundant in August 2015. Roach fed almost exclusively on herbivorous cladocerans, especially Bosmina that consisted $60-95 \%$ of their diet (Fig. 12).

\section{Discussion}

The short-term response of the smelt population on hypolimnetic aeration was quite expected, while the long-term response was the opposite to our hypothesis. Our study revealed that cladoceran body size readily responds to changes in planktivorous fish community and that especially the presence of very dense smelt stock relates to small size of herbivorous cladocerans in the zooplankton community.

The hypothesis that hypolimnetic aeration would collapse the smelt population was based on the knowledge that aeration increases the hypolimnetic 


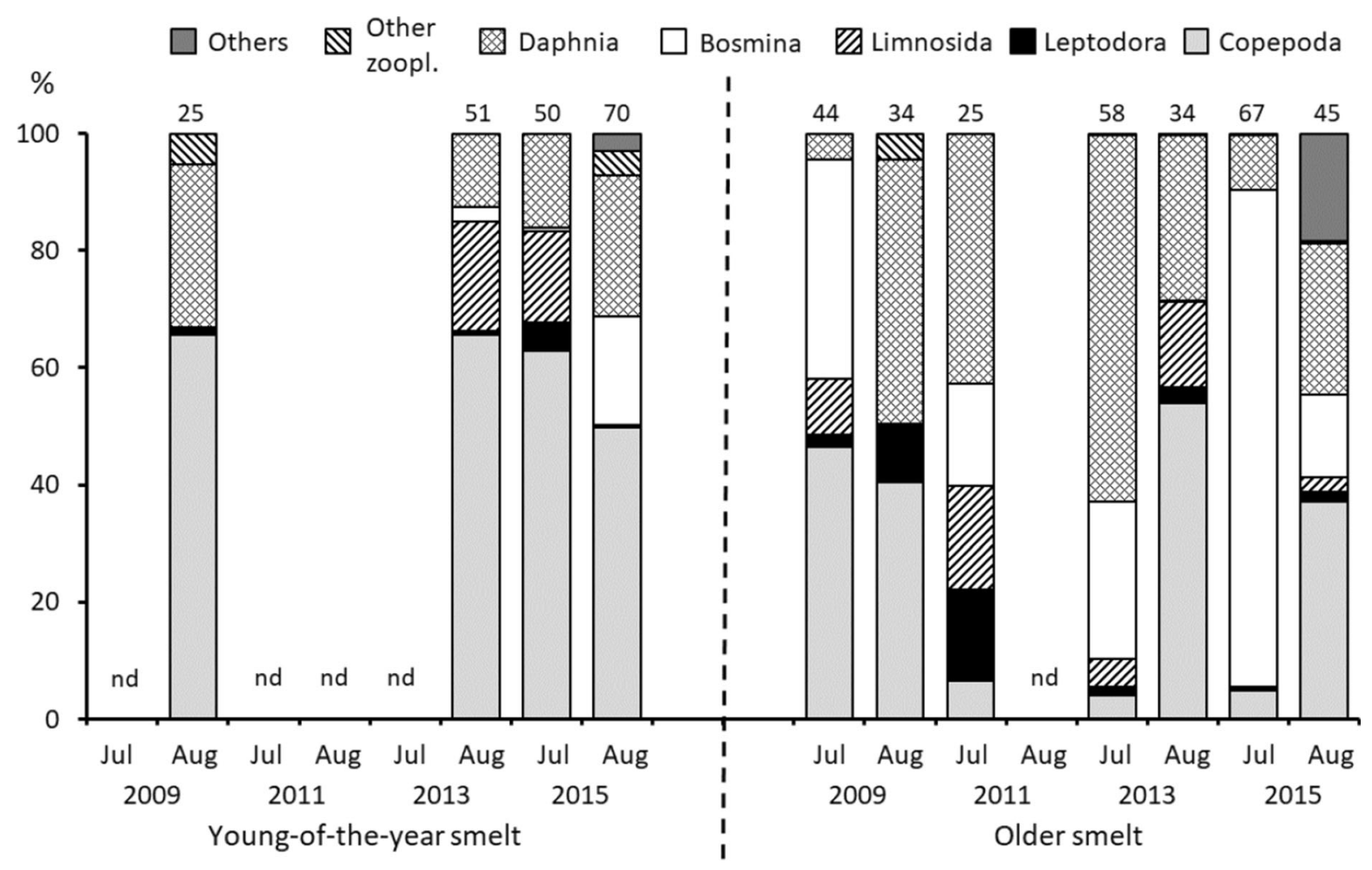

Fig. 11 The diet of young-of-the-year (left) and older smelt (right) in early July and late August during years 2009, 2011, 2013 and 2015. nd = no data

temperature which is harmful for this cold-water fish species (Lantry \& Stewart, 1993; Kangur et al., 2007). The collapses in warm summers 2010 and 2011 were caused by low hypolimnetic oxygen concentrations accompanied with excessively high epilimnetic temperatures. A similar collapse in corresponding physical conditions was documented also in 2002 (Ruuhijärvi et al., 2005). Horppila et al. (2015) noticed that due to higher oxygen solubility in the cooler surface water and weaker warming effect of aeration in 2012, aeration was able to maintain a higher $\mathrm{O}_{2}$ concentration in the hypolimnion than in 2011.

During summers 2012-2017 with tolerable hypolimnetic oxygen concentrations for smelt, the increased hypolimnetic temperatures were expected to prevent the recovery of the stock. However, the late summer temperature (ca. $17-18^{\circ} \mathrm{C}$ ) appeared to be tolerable for young-of-the-year smelt, and the population reached even a much higher density than before aeration. The density and biomass during the last three years of aeration were even multifold compared with those in other smelt-dominated eutrophic lakes in southern Finland $\left(<35,000\right.$ ind. $\mathrm{ha}^{-1}$ and $<35 \mathrm{~kg} \mathrm{ha}^{-1}$, Malinen \& Tuomaala, 2005; Malinen, 2018). The present smelt biomass is also much higher than those documented in other large Finnish lakes (Jurvelius et al., 2005) and North American lakes that have been invaded by rainbow smelt Osmerus mordax (Mitchill) (Warner et al., 2009; Stockwell et al., 2007; Gaeta et al., 2015). It appears that the variation of smelt abundance in Lake Vesijärvi during the aeration experiment is much higher than that of smelt stocks without such disturbance suggesting that aeration changed smelt stock dynamics.

Hypolimnetic aeration probably created optimal thermal conditions for young-of-the-year smelt, which prefer warmer water and are not as dependent on thermal stratification as adult smelt (Ivanova, 1982). For instance, in nearby Lake Hiidenvesi, young-ofthe-year smelt occur regularly at $18-20{ }^{\circ} \mathrm{C}$ in late summer (Malinen et al., 2005). Mixing surface water with deep water has been shown to raise hypolimnetic temperature and increase the populations of juvenile warm-water fish (Gauthier et al., 2014). In the 


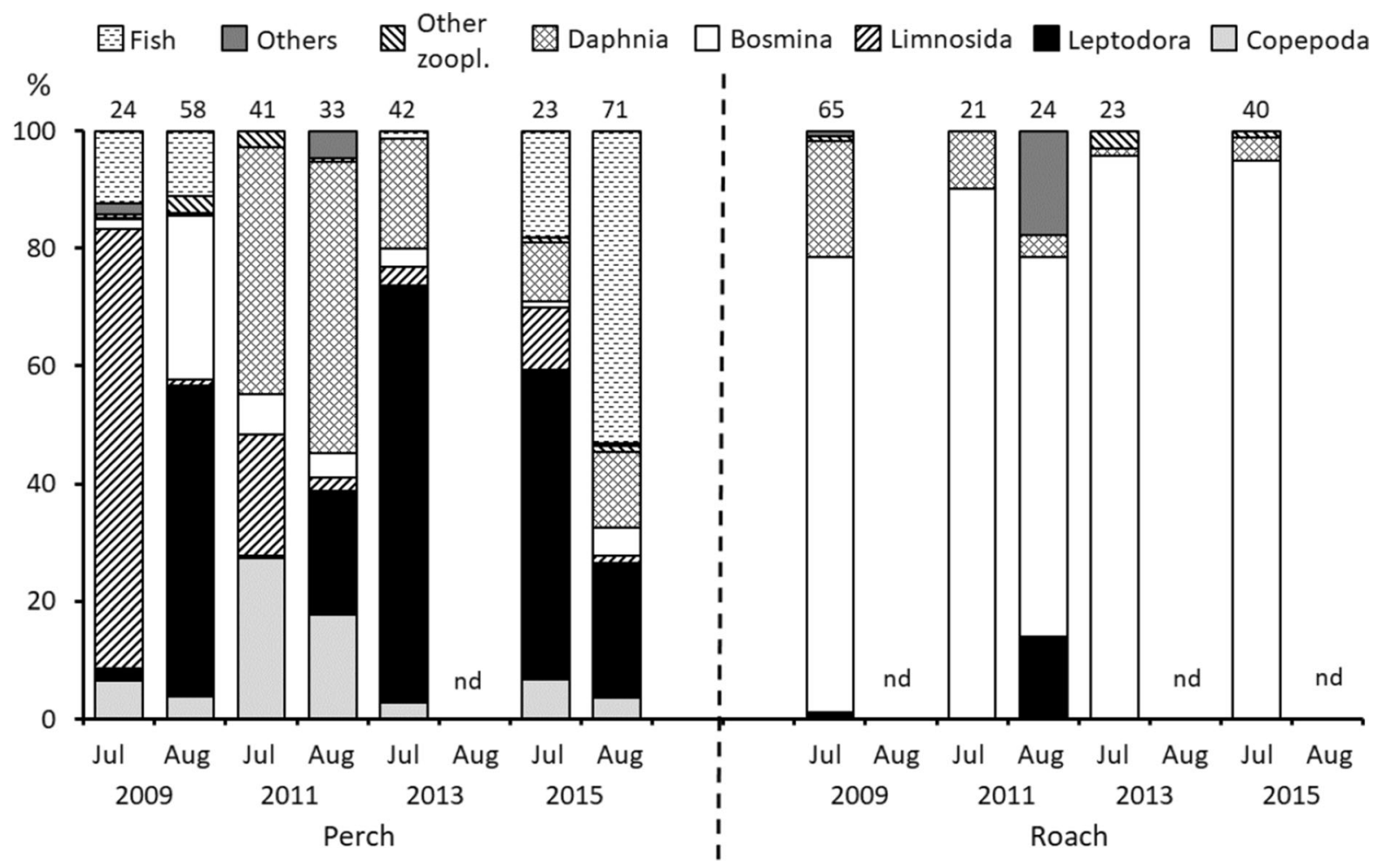

Fig. 12 The diet of pelagic perch $(<15 \mathrm{~cm})$ and roach in early July and late August during years 2009, 2011, 2013 and 2015. nd = no data

Enonselkä basin of Lake Vesijärvi, the temperature regime was unsuitable for older smelt, leading to their high mortality or migration to other basins with more favourable environmental conditions and, consequently, the age-distribution became strongly predominated by young-of-the-year fish. This kind of plasticity of population parameters according to physical environment is typical for smelt (Kriksunov \& Shatunovskiy, 1979; Ivanova, 1982; Volodin \& Ivanova, 1987). Smelt populations in non-stratifying shallow lakes have typically high mortality and are dominated by young-of-the-year fish. The smelt populations of this kind can fluctuate dramatically depending on summer temperature and developing year-class, which took place also in Lake Vesijärvi. Similar smelt population dynamics has been documented in another Finnish lake, shallow (max. depth $10 \mathrm{~m}$ ) Lake Tuusulanjärvi, which has been managed by aeration (Rask et al., 2020).

We hypothesised that hypolimnetic aeration would result in environmental conditions highly adverse to smelt, leading to a population collapse and the replacement of the pelagic fish community by other species. In the worst-case scenario, the pelagic fish assemblage could have turned into the dominance by roach, which was the case in the 1980s, when cyanobacterial blooms were very common (Peltonen et al., 1999a). Roach may be the most adverse species in terms of water quality, being an effective planktivore and capable of utilizing both pelagic and littoral resources (Horppila, 1994; Horppila et al., 2000; Řiha et al., 2015). Roach-mediated phosphorus movement from littoral to pelagial was interpreted as the main mechanism supporting algal blooms before the largescale biomanipulation (Kairesalo et al., 1999). In addition, roach has a long lifespan and grows much larger than smelt. It is capable to form a large and constant fish biomass and is less vulnerable to predation by piscivores compared to smelt and young perch. Therefore, roach and bream have been effectively managed by fishing also during the years of hypolimnetic aeration to prevent the increase of their stocks (Ruuhijärvi \& Ala-Opas, 2014; Ruuhijärvi et al., 2018). 
Despite the collapse of the smelt population being a short-term phenomenon, we documented an increase in perch density in the pelagial habitat of Enonselkä basin. This was an expected response, as perch is a generalist species capable of living in various habitats in a stratified lake. Perch larvae have a pelagic period when they disperse widely in the lake area (Urho, 1996). Perch fry can survive in pelagial, even in deeper water layers (Sajdlová et al., 2018) with hypoxic waters offering refuge from predators and often rich in zooplankton prey (Vejř́k et al., 2016). Young perch feed mainly on large cladocerans Daphnia, Limnosida, Diaphanosoma and Leptodora in the pelagial of Lake Vesijärvi. The elevated biomasses of Leptodora during the aeration period probably also favoured perch. However, as perch readily shift to piscivory, even at smaller size than $15 \mathrm{~cm}$ in length, it is probably among the least adverse species in terms of top-down control. Moreover, its diet consists of herbivorous cladocerans to a lesser extent compared to that of roach and smelt. The density of roach in pelagial did not increase during the low density of smelt. Young roach live in the littoral zone in Lake Vesijärvi, while adult individuals reside also in pelagial areas (Horppila \& Peltonen, 1994). However, roach was less abundant during this study than before the biomanipulation period of the Enonselkä basin in 1980s, probably due to the recovered pikeperch stock and management fishing targeted at cyprinid species (Ruuhijärvi et al., 2005; Salonen et al., 2020). Based on the fluctuating pelagic biomass estimates of roach, it appears that the present, less abundant roach stock utilises the pelagic habitat only during the midsummer peak of cladocerans. The diet of pelagic roach consists largely of Bosmina, which is generally abundant in late June-early July, and this may favour Daphnia in terms of competition for food. In late summer, roach utilize most likely other food resources in shallow areas.

The variation in pelagic bream biomass, on the other hand, appears to be driven by oxygen depletion episodes in hypolimnion. During tolerable oxygen concentration, bream stay near-bottom-layer where they cannot be found by hydroacoustics and trawling but during depletion episodes, they are forced to ascend to epilimnion where they can be readily found. This suggests that hydroacoustics and pelagic trawling may bias bream abundance estimation and the validity of estimates should be evaluated against prevailing hypolimnetic oxygen conditions. Recent studies in August 2018, when severe oxygen depletion prevailed in water column deeper than 10-15 m, and at the same time abundant pelagic bream populations were detected, give further support for this phenomenon (unpublished data).

Prior to the present study, smelt was considered a less adverse species for top-down control than cyprinids. It has typically more versatile diet also consisting of copepods and small fish (Vinni et al., 2004, this study). In addition, as a small-sized fish, it is a suitable prey for pikeperch and perch (Peltonen et al., 1996; Horppila et al., 2000; this study) and does not typically build up high biomasses (Malinen, 2018). Moreover, it inhabits only the pelagic area and does not transfer nutrients from littoral to pelagial. However, the aeration experiment revealed that exceptionally high smelt densities may be harmful for the topdown control of phytoplankton through decline in cladoceran body size and, therefore, grazing potential.

The main predatory fish, $>15 \mathrm{~cm}$ perch and pikeperch were very abundant in 2010-2011 when aeration was started. The collapse of smelt stock reduced the prey resources of predatory fish and thus the production of the stocks. Good catches of pikeperch by recreational fishermen in 2010-2011, 5-9 $\mathrm{kg} \mathrm{ha}^{-1}$ measured in a fishing questionnaire (Ruuhijärvi \& Ala-Opas, 2014), increased the fishing pressure leading to too heavy exploitation of the stock in 2012-2013. Despite the recovery of smelt stock in 2014-2017, the abundance of predatory fish continued declining. The NPUE (number of fish net ${ }^{-1}$ night $^{-1}$ ) of NORDIC gill nets has a positive but non-linear relationship to perch density in the sampling area (Olin et al., 2016). The saturation of the NORDIC gill net by caught fish is, however, not remarkable when the CPUE ( $\mathrm{kg} \mathrm{net}{ }^{-1}$ night $^{-1}$ ) is less than $3 \mathrm{~kg}$ (Prchalová et al., 2011). Thus, sampling with NORDIC gill nets can be considered as a reliable method to estimate the changes in the abundance of perch and pikeperch in the Enonselkä basin of Lake Vesijärvi.

Abundant stocks of predatory fish are essential for trophic cascades to control planktivory on herbivorous zooplankton in eutrophic lakes suffering from algal blooms. In Lake Vörtsjärv, Nöges et al. (2016) found negative correlation between the abundance of pikeperch and blooms of filamentous cyanobacteria. However, perch and pikeperch are the main target species of recreational fishermen in Lake Vesijärvi 
and high fishing mortality, together with natural variation in recruitment, can hamper the ability of these piscivores to control the rapidly increasing stock of smelt and other planktivores. Recent studies on growth, maturity and fishery management of the pikeperch in Lake Vesijärvi suggested raising the minimum size limit from 42 to $50 \mathrm{~cm}$ and fishing restrictions as sustainable management options (Vainikka et al., 2017; Olin et al., 2018).

As hypothesised, the collapse of the smelt population both after 2002-2003 (Ruuhijärvi et al., 2005) and 2010 (this study) resulted in increased cladoceran body size (Vakkilainen \& Kairesalo, 2005; this study), indicating reduced predation pressure on zooplankton. Smelt density was very high also at the turn of the century, before 2002, but not as massive as in 2015, when the increase in planktivory by smelt population caused a major drop of cladoceran body size especially in late summer. The reason why very low planktivory in 2011 was not reflected as increasing size of cladocerans in late summer may be explained by hypolimnetic aeration, which has been suggested to lead to a loss of hypolimnetic refuge and stronger predator-prey interactions with fish (Gauthier et al., 2014; Sastri et al., 2014). In the Enonselkä basin, the pumping of epilimnetic water to hypolimnion was initiated only after hypolimnetic oxygen concentration decreased below $4 \mathrm{mg}^{-1}$ and, therefore, water columns were mixed by using the Mixox pumps from early June until the end of August. Thus, during this period even minor populations of planktivorous fish may have effectively preyed on large-bodied cladocerans, which suffered from the lack of their hypolimnetic refuge and the turbulent environment (cf. Cantin et al., 2011, Sastri et al., 2014). This assumption was supported by increasing cladoceran body size despite the recovering smelt population in 2013, when the lake stratified strongly, leaving hypolimnetic water cold and rich in oxygen. Because of this beneficial situation, aeration was started over a month later than usual, 12th July.

Hypolimnetic aeration by mixing epilimnetic water to the hypolimnion has not decreased phosphorus concentrations in the epilimnion of the Enonselkä basin. Increased turbulence and the exposure of a larger amount of lake sediment to higher temperature has shown to lead to enhanced recycling of organic material, greater mineralisation rate and associated nutrient release (Cantin et al., 2011; Niemistö et al.,
2016). It has been argued that the old paradigm on phosphorus release from anoxic lake sediments is only valid in some special cases (Hupfer \& Lewandowski, 2008) and that increased hypolimnetic dissolved oxygen concentration does not reduce phosphorus release from sediments, not to mention permanent phosphorus retention (Gächter \& Müller, 2003). Even if the expected results would have been observed, the effect would only be temporary and the primary measure to achieve long-term improvement of lake water is the reduction of external nutrient loading (Liboriussen et al., 2009). In the Enonselkä basin TP concentrations increased during the last years of this study, despite hypolimnetic aeration. This has probably contributed to the occasionally elevated levels of cyanobacterial biomasses with filamentous species, such as Planktothrix agardhii (Gomont) (>60\% of phytoplankton biomass in 2016). Mixing water columns may favour the turbulent tolerant species of Planktothrix (Cooke et al., 2005; Visser et al., 2016). This, in turn, has been detrimental to food-collection mechanisms of larger Daphnia individuals (Gliwicz, 2003) and has caused low availability and utilisation of high-quality food, essential for the growth and reproduction of Daphnia (Taipale et al., 2019). The keystone species Daphnia therefore suffer from multiple adverse disturbances in Lake Vesijärvi, including the loss of the hypolimnetic refuge from predation by fish, a phenomenon documented also previously as a response to lake mixing (Gauthier et al., 2014). The increase of phosphorus, dominance of cyanobacteria and less control of phytoplankton by zooplankton have been listed as possible undesirable effects of artificial circulation (Cooke et al., 2005). These kinds of outcomes were detected, though not significantly in the Enonselkä basin of Lake Vesijärvi after the onset of hypolimnetic aeration.

\section{Concluding remarks}

The structure and dynamics of the pelagic food web in Enonselkä basin were altered remarkably by the pumping of water from epilimnion to hypolimnion. One of the most conspicuous results was the development of an exceptionally dense smelt population that was strongly dominated by young-of-the-year individuals. This induced high predation pressure on zooplankton and a decline in cladoceran body size. 
Lake productivity, measured as phosphorus levels, remained unaltered during years of aeration, so the decreased control on phytoplankton by smaller-bodied zooplankton probably contributed to high algal biomasses with occasional blooms of cyanobacteria. These blooms, in turn, could reinforce the eutrophic system regime through further reducing the control of phytoplankton by zooplankton.

Acknowledgements Open access funding provided by Natural Resources Institute Finland (LUKE). We thank Lake Vesijärvi Foundation and Lahti Aqua PLC for funding the research. Zooplankton study in early 2000s' was done in a project financed by European Regional Development Fund of the European Union (Contract CC320742). Martin Čech as a referee gave valuable comments to the manuscript and John Loehr kindly checked the English language. Special thanks to Hannu Yläoutinen and excellent field workers of Natural Resources Institute Finland, University of Helsinki and City of Lahti.

Open Access This article is licensed under a Creative Commons Attribution 4.0 International License, which permits use, sharing, adaptation, distribution and reproduction in any medium or format, as long as you give appropriate credit to the original author(s) and the source, provide a link to the Creative Commons licence, and indicate if changes were made. The images or other third party material in this article are included in the article's Creative Commons licence, unless indicated otherwise in a credit line to the material. If material is not included in the article's Creative Commons licence and your intended use is not permitted by statutory regulation or exceeds the permitted use, you will need to obtain permission directly from the copyright holder. To view a copy of this licence, visit http://creativecommons.org/licenses/by/4.0/.

\section{References}

Aku, P. M. K., L. G. Rudstam \& W. M. Tonn, 1997. Impact of hypolimnetic oxygenation on the vertical distribution of cisco (Coregonus artedi) in Amisk Lake, Alberta. Canadian Journal of Fisheries and Aquatic Sciences 54: 2182-2195.

Andersen, T., J. Carstensen, E. Hernández-García, \& C. M. Duarte, 2008. Ecological thresholds and regimes shifts: approaches to identification. Trends in Ecology and Evolution 24: 49-57.

Anttila, S., M. Ketola, K. Kuoppamäki \& T. Kairesalo, 2013. Identification of a biomanipulation-driven regime shift in Lake Vesijärvi: implications for lake management. Freshwater Biology 58: 1494-1502.

Appelberg, M., H.-M. Berger, T. Hesthagen, E. Kleiven, M. Kurkilahti, J. Raitaniemi \& M. Rask, 1995. Development and intercalibration of methods in Nordic freshwater fish monitoring. Water, Air, \& Soil Pollution 85: 401-406.
Austin, P. C. \& J. E. Hux, 2002. A brief note on overlapping confidence intervals. Journal of Vascular Surgery 36: 194-195.

Cantin, A., B. E. Beisner, J. M. Gunn, Y. T. Prairie \& J. G. Winter, 2011. Effects of thermocline deepening on lake plankton communities. Canadian Journal of Fisheries and Aquatic Sciences 68: 260-276.

Cooke, G. D., E. B. Welch, S. A. Peterson \& S. A. Nichols, 2005. Restoration and management of lakes and reservoirs, 3rd ed. Taylor \& Francis, Boca Raton, London.

Diaz, R. J., 2001. Overview of hypoxia around the world. Journal of Environmental Quality 30: 275-281.

Gaeta, J. W., T. R. Hrabik, G. G. Sass, B. M. Roth, S. J. Gilbert. \& M. J. Vander Zanden, 2015. A whole-lake experiment to control invasive rainbow smelt (Actinoperygii, Osmeridae) via overharvest and a food web manipulation. Hydrobiologia 746: 433-444.

Gauthier, J., Y. T. Prairie \& B. E. Beisner, 2014. Thermocline deepening and mixing alter zooplankton phenology, biomass and body size in a whole-lake experiment. Freshwater Biology 59: 998-1011.

Gliwicz, M., 2003. Between hazards of starvation and risk of predation: the ecology of offshore animals. Excellence in Ecology 12, International Ecology Institute, Germany.

Gächter, R. \& B. Müller, 2003. Why the phosphorus retention of lakes does not necessarily depend on the oxygen supply to their sediment surface. Limnology and Oceanography 48 : 929-933.

Hansson, L.-A., H. Annadotter, E. Bergman, S. F. Hamrin, E. Jeppesen, T. Kairesalo, E. Luokkanen, P.-Å. Nilsson, M. Sondergaard \& J. Strand, 1998. Biomanipulation as an application of food-chain theory: constrains, synthesis and recommendations for temperate lakes. Ecosystems 1: 558-574.

Heald, E., T. Hrabik, Y. Li, Z. J. Lawson, S. R. Carpenter \& M. J. Vander Zanden, 2017. The effects of experimental whole-lake mixing on horizontal spatial patterns of fish and zooplankton. Aquatic Sciences 79: 543-556.

Horppila, J. 1994. The diet and growth of roach (Rutilus rutilus (L.)) in Lake Vesijärvi and possible changes in the course of biomanipulation. Hydrobiologia 294. 35-41.

Horppila, J. \& H. Peltonen, 1994. The fate of roach Rutilus rutilus stock under an extremely strong fishing pressure and its predicted development after the cessation of mass removal. Journal of Fish Biology 45: 777-786.

Horppila, J., K. Nyberg, H. Peltonen \& T. Turunen, 1996. Effects of five years of intensive trawling on a previously unexploited smelt stock. Journal of Fish Biology 49: 329-340.

Horppila, J., H. Peltonen, T. Malinen, E. Luokkanen \& T. Kairesalo, 1998. Top-down or bottom-up effects of fish: issues of concern in biomanipulation of lakes. Restoration Ecology 6: 20-28.

Horppila, J., J. Ruuhijärvi, M. Rask, C. Karppinen, K. Nyberg, $\&$ M. Olin, 2000. Seasonal changes in the diets and relative abundances of perch and roach in the littoral and pelagic zones of a large lake. Journal of Fish Biology 56: 51-72.

Horppila, J., P. Köngäs, J. Niemistö, \& S. Hietanen, 2015. Oxygen flux and penetration depth in the sediments of aerated and non-aerated lake basins. International Review of Hydrobiology 2015, 100, 106-115. 
Hupfer, M. \& J. Lewandowski, 2008. Oxygen Controls the Phosphorus Release from Lake Sediments - a Long-Lasting Paradigm in Limnology. International Review of Hydrobiology 93: 415-432.

Hynes, H. B. N., 1950. The food of fresh-water sticklebacks (Gasterosteus aculeatus and Pygosteus pungitius), with review of methods used in studies of the food of fishes. Journal of Animal Ecology 19: 35-58.

Ivanova, M. N., 1982. The influence of environmental conditions on the population dynamics of smelt, Osmerus eperlanus (Osmeridae). Journal of Ichthyology 22: 45-51.

Jolly, G. M. \& I. Hampton, 1990. Some problems in the statistical design and analysis of acoustic surveys to assess fish biomass. Rapports et Procès-verbaux des Réunions Conseil permanent international pour L'Exploration de la Mer. 189: 415-420.

Jurvelius, J. \& I. Sammalkorpi, 1995. Hydroacoustic monitoring of the distribution, density and the mass-removal of pelagic fish in a eutrophic lake. Hydrobiologia 316: 33-41.

Jurvelius, J., H. Auvinen, I. Kolari \& T. J. Marjomäki, 2005. Density and biomass of smelt (Osmerus eperlanus) in five Finnish lakes. Fisheries Research 73: 353-361.

Kairesalo, T., S. Laine, E. Luokkanen, T. Malinen \& J. Keto, 1999. Direct and indirect mechanisms behind successful biomanipulation. Hydrobiologia 395/396: 99-106.

Kangur, A., P. Kangur, K. Kangur \& T. Möls, 2007. The role of temperature in the population dynamics of smelt Osmerus eperlanus eperlanus m. spirinchus Pallas in Lake Peipsi (Estonia/Russia). Hydrobiologia 584: 433-441.

Keskinen, T., J. Lilja, P. Högmander, J. A. Holmes, J. Karjalainen \& T. J. Marjomäki, 2012. Collapse and recovery of the European smelt (Osmerus eperlanus) population in a small boreal lake - an early warning of the consequences of climate change. Boreal Environment Research 17: 398-410.

Keto, J., 1982. The recovery of L. Vesijärvi following sewage diversion. Hydrobiologia 86: 195-199.

Kitchell, J. A. \& J. F. Kitchell, 1980. Size-selective predation, light transmission and oxygen stratification: Evidence from the recent sediments of manipulated lakes. Limnology and Oceanography 25: 389-402.

Kocovsky, P. M., L. G. Rudstam, D. L. Yule, D. M. Warner, T. Schaner, B. Pientka, J. W. Deller, H. A. Waterfield, L. D. Witzel \& P. J. Sullivan, 2013. Sensitivity of fish density estimates to standard analytical procedures applied to Great Lakes hydroacoustic data. Journal of Great Lakes Research 39: 655-662.

Kriksunov, Ye. A. \& M. I. Shatunovskiy, 1979. Some questions of population structure variability in the smelt, Osmerus eperlanus. Journal of Ichtyology 19: 48-55.

Lantry, B. F. \& D. J. Stewart, 1993. Ecological energetics of rainbow smelt in the Laurentian Great Lakes: An interlake comparison. Transactions of the American Fisheries Society 122: 951-976.

Lawson, Z. J., M. J. Vander Zanden, C. A. Smith, E. Heald, T. R. Hrabik \& S. R. Carpenter, 2015. Experimental mixing of a north-temperate lake: testing the thermal limits of a coldwater invasive fish. Canadian Journal of Fisheries and Aquatic Sciences 72: 926-937.

Liboriussen, L., M. Sondergaard, E. Jeppesen, I. Thorsgaard, S. Grunfeld, T. S. Jakobsen \& K. Hansen, 2009. Effects of hypolimnetic oxygenation on water quality: results from five Danish lakes. Hydrobiologia 625: 157-172.

MacLennan, D. N., P. G. Fernandes \& J. Dalen, 2002. A consistent approach to definitions and symbols in fisheries acoustics. ICES Journal of Marine Science 59: 365-369.

Malinen, T., 2018. Hydroacoustic fish stock assessment in southern and northern boreal lakes - potential and constraints. PhD dissertation. Faculty of Biological and Environmental Sciences, University of Helsinki. Hansaprint Oy, Turenki. 62 pp. https://urn.fi/URN:ISBN:978951-51-4465-2

Malinen, T. \& A. Tuomaala, 2005. Comparison of day and night surveys in hydroacoustic assessment of smelt (Osmerus eperlanus) density in Lake Hiidenvesi. Archiv für Hydrobiologie Special Issues: Advanced Limnology 59: 161-172.

Malinen, T., A. Tuomaala \& H. Peltonen, 2005. Vertical and horizontal distribution of smelt (Osmerus eperlanus) and implications of distribution patterns on stock assessment. Archiv für Hydrobiologie Special Issues Advances in Limnology 59: 141-159.

Niemistö, J., P. Köngäs, L. Härkönen \& J. Horppila, 2016. Hypolimnetic aeration intensifies phosphorus recycling and increases organic material sedimentation in a stratifying lake: Effects through increased temperature and turbulence. Boreal Environment Research 21: 571-587.

Nykänen, M., T. Malinen, K. Vakkilainen, M. Liukkonen \& T. Kairesalo, 2010. Cladoderan community responses to biomanipulation and reoligotrophication in Lake Vesijärvi, Finland, inferred from cladoceran remains in annually laminated sediment. Freshwater Biology 55: 1164-1181.

Nöges, T., A. Järvalt, J. Haberman, P. Zingel \& P. Nöges, 2016. Is fish able to regulate filamentous blue-green dominated phytoplankton? Hydrobiologia 780: 59-69.

Olin, M. \& T. Malinen, 2003. Comparison of gillnet and trawl in diurnal fish community sampling. Hydrobiologia 506-509: 443-449.

Olin, M., M. Rask, J. Ruuhijärvi, M. Kurkilahti, P. Ala-Opas \& O. Ylönen, 2002. Fish community structure in mesotrophic and eutrophic lakes of southern Finland: the relative abundances of percids and cyprinids along a trophic gradient. Journal of Fish Biology 60: 593-612.

Olin, M., T. Malinen \& J. Ruuhijärvi, 2009. Gillnet catch in estimating the density and structure of fish community comparison of gillnet and trawl samples in a eutrophic lake. Fisheries Research 96: 88-94.

Olin, M., J. Tiainen, M. Kurkilahti, M. Rask \& H. Lehtonen, 2016. An evaluation of gillnet CPUE as an index of perch density in small forest lakes. Fisheries Research 173: 20-25.

Olin, M., A. Vainikka, T. Roikonen, J. Ruuhijärvi, H. Huuskonen, M. Kotakorpi, S. Vesala, P. Ala-Opas, J. Tiainen, L. Nurminen \& H. Lehtonen, 2018. Trait-related variation in reproductive characteristics of female pikeperch (Sander lucioperca). Fisheries Management and Ecology 25: 220-232.

Peltonen, H., T. Malinen \& A. Tuomaala, 2006. Hydroacoustic in situ target strength of smelt (Osmerus eperlanus (L.)). Fisheries Research 80: 190-195.

Peltonen, H., H. Rita \& J. Ruuhijärvi 1996. Diet and prey selection of pikeperch (Stizostedion lucioperca (L.)) in 
Lake Vesijärvi analysed with a logit model. Annales Zoologici Fennici 33: 481-487.

Peltonen, H., J. Ruuhijärvi, T. Malinen, J. Horppila, M. Olin \& J. Keto, 1999a. The effects of food-web management on fish assemblage dynamics in a north temperate lake. Journal of Fish Biology 55: 54-67.

Peltonen, H., J. Ruuhijärvi, T. Malinen \& J. Horppila, 1999b. Estimation of roach (Rutilus rutilus (L.)) and smelt (Osmerus eperlanus (L.)) stocks with virtual population analysis, hydroacoustics and gillnet CPUE. Fisheries Research 44: 25-36.

Prchalová, M., T. Mrkvicka, J. Peterka, M. Čech, L. Berec, \& J. Kubečka, 2011. A model of gillnet catch in relation to the catchable biomass, saturation, soak time and sampling period. Fisheries Research 107, 201-209.

Rask, M., 1989. A note of the diet of roach, Rutilus rutilus L., and other cyprinids at Tvärminne, northern Baltic Sea. Aqua Fennica 19: 19-27.

Rask, M., T. Malinen, M. Olin, H. Peltonen, J. Ruuhijärvi, S. Vesala \& J. Hietala, 2020. Responses of the fish community in a eutrophicated lake to long-term food web management assessed by multiple sampling methods. Hydrobiologia. This issue

Řiha, M., D., Ricard, M. Vašek, M. Prchalová, T. Mrkvicka, T. Jůza, M. Čech, V. Drastık, M. Muska, M. Kratochvil, J. Peterka, M. Tuser, J. Seda, P. Blabolil, M. Blaha, J. Wanzenböck \& J. Kubečka, 2015. Patterns in diel habitat use of fish covering the littoral and pelagic zones in a reservoir. Hydrobiologia 747:111-131.

Ruuhijärvi, J. \& P. Ala-Opas, 2014. Vesijärven kalataloudellinen tarkkailu 2011-2013 (Monitoring of fishery of Lake Vesijärvi in 2011-2013). RKTL:n työraportteja (Reports of Finnish Game and Fisheries Research Institute) 30/2014: 1-41. (In Finnish). https://jukuri.luke.fi/handle/10024/ 519936.

Ruuhijärvi, J., T. Malinen, P. Ala-Opas \& A. Tuomaala, 2005. Fish stocks of Lake Vesijärvi: from nuisance to flourishing fishery in 15 years. Verhandlungen des Internationalen Verein Limnologie 29: 384-389.

Ruuhijärvi, J., P. Ala-Opas \& K. Kulo, 2018. Vesijärven kalataloudellinen tarkkailu 2014-16 (Monitoring of fishery of Lake Vesijärvi in 2014-16). Luonnonvara ja biotalouden tutkimus (Natural resources and bioeconomy studies) 8/2018. 1-42. (In Finnish). https://jukuri.luke.fi/ handle/10024/541511.

Sajdlová, Z., J. Frouzová, V. Draštík, T. Jůza, J. Peterka, M. Prchalová, M. Říha, M. Vašek, J. Kubečka \& M. Čech, 2018. Are diel vertical migrations of European perch (Perca fluviatilis L.) early juveniles under direct control of light intensity? Evidence from a large field experiment. Freshwater Biology 63: 473-482.

Salmi, P., I. Malin \& K. Salonen, 2014. Pumping of epilimnetic water into hypolimnion improves oxygen but not necessarily nutrient conditions in a lake recovering from eutrophication. Inland Waters 4: 425-434.

Salonen, K., J. Sarvala, J. Horppila, J. Keto, I. Malin, T. Malinen, J. Niemistö \& J. Ruuhijärvi, 2020. Development of Lake Vesijärvi through four decades of remediation efforts. Hydrobiologia. This issue

Sastri, A. R., J. Gauthier, P. Juneau \& B. E. Beisner, 2014. Biomass and productivity responses of zooplankton communities to experimental thermocline deepening. Limnology and Oceanography 59: 1-16.

Sawada, K., M. Furusawa \& M. J. Williamson, 1993. Conditions for the precise measurements of fish TS in situ. The Journal of the Acoustical Society of Japan 20: 73-79.

Schindler, D. W., 2006. Recent advances in the understanding and management of eutrophication. Limnology and Oceanography 51: 351-363.

Shotton, R. \& G. P. Bazigos, 1984. Techniques and considerations in the design of acoustic surveys. Rapports et Procèsverbaux des Réunions Conseil permanent international pour L'Exploration de la Mer. 184: 34-57.

Simmonds, J. \& D. MacLennan, 2005. Fisheries acoustic: theory and practice. Blackwell Science, Oxford. 2 ed. 437 pp.

Stockwell, J. D., D. L. Yule, T. R. Hrabik, J. V. Adams, O. Gorman \& B. V. Holbrook, 2007. Vertical distribution of fish biomass in Lake Superior: Implications for day bottom trawl surveys. North American Journal of Fisheries Management 27: 735-749.

Taipale, S. J., S. L. Aalto, A. W. E. Galloway, K. Kuoppamäki, P. Nzobeuh, \& E. Peltomaa, 2019. Eutrophication and browning influence Daphnia nutritional ecology. Inland Waters 9: 374-394.

Urho, L., 1996. Habitat shifts of perch larvae as survival strategy. Annales Zoologici Fennici 33: 329-340.

Vakkilainen, K. \& T. Kairesalo, 2005. Zooplankton community responses to the fish stock management of Lake Vesijärvi, southern Finland: changes in the cladoceran body size in 1999-2003. Verhandlungen der Internationalen Vereinigung für Theoretische und Angewandte Limnologie 29: 488-490.

Vakkilainen, K., T. Kairesalo, J. Hietala, D. Balayla, E. Bécares, W. van de Bund, E. van Donk, M. Fernández-Aláez, M. Gyllström, L.-A. Hansson, M. R. Miracle, B. Moss, S. Romo, J. Rueda \& D. Stephen, 2004. Response of zooplankton to nutrient enrichment and fish in shallow lakes: a pan-European mesocosm experiment. Freshwater Biology 49: 1619-1632.

Valtanen, M., N. Sillanpää, H. Setälä, 2014. The effects of urbanisation on runoff pollutant concentrations, loadings and their seasonal patterns under cold climate. Water, Air, \& Soil Pollution 225: 1977.

Vainikka, A., M. Olin, J. Ruuhijärvi, H. Huuskonen, R. Eronen \& P. Hyvärinen, 2017. Model-based evaluation of the management of pikeperch (Sander lucioperca) using minimum and maximum size limits. Boreal Environment Research 22: 187-212.

Vanderploeg, H. A., S. A. Ludsin, J. F. Cavaletto, T. Höök, S. A. Pothoven, S. B. Brandt, J. R. Liebig \& G. A. Lang, 2009. Hypoxic zones as habitat for zooplankton in Lake Erie: Refuges from predation or exclusion zones? Journal of Experimental Marine Biology and Ecology 381: 108-120.

Warner, D. M., J. S. Schaeffer \& T. P. O’Brien, 2009. The Lake Huron pelagic fish community: persistent spatial pattern along biomass and species composition gradients. Canadian Journal of Fisheries and Aquatic Sciences 66: 1199-1215.

Vejř́ík, L., I. Matějíčková, T. Jůza, J. Frouzová, J. Sed'a, P. Blabolil, D. Ricard, M. Vašek, J. Kubečka, M. Říha \& M. Čech, 2016. Small fish use the hypoxic pelagic zone as a refuge from predators. Freshwater Biology 61: 899-913. 
Windell, J. T., 1971. Food analysis and rate of digestion. In: Ricker, W. E. (ed.): Methods for assessment of fish production in fresh waters. IBP Handbook 3. Blackwell Scientific Publications. Oxford.

Vinni, M., J. Lappalainen, T. Malinen \& H. Peltonen, 2004. Seasonal bottlenecks in diet shifts and growth of smelt in a large eutrophic lake. Journal of Fish Biology 64: 567-579.

Visser, P. M., B. W. Ibelings, M. Bormans \& J. Huisman, 2016. Artificial mixing to control cyanobacterial blooms: a review. Aquatic Ecology 50: 423-441.

Volodin, V. M. \& M. N. Ivanova, 1987. Variation in population structure of smelt, Osmerus eperlanus and Tyulka,
Clupeonella cultriventris caspia, during adaptation in the reservoirs of the Volga Basin. Journal of Ichthyology 27: 81-87.

Vøllestad, L., 1985. Resource partitioning of roach Rutilus rutilus and bleak Alburnus alburnus in two eutrophic lakes in South-Eastern Norway. Holarctic Ecology 8: 88-92.

Publisher's Note Springer Nature remains neutral with regard to jurisdictional claims in published maps and institutional affiliations. 